Joseph C. Miller Memorial Lecture Series

eds. Abdelkader Al Ghouz, Jeannine Bischoff, Sarah Dusend

\title{
Caroline Laske
}

Medieval Women in the Très Ancien

Coutumier de Normandie. Textual Representation of Asymmetrical Dependencies 
Medieval Women in the Très Ancien Coutumier de Normandie. Textual Representation of Asymmetrical Dependencies 


\section{Joseph C. Miller Memorial Lecture Series}

eds. Abdelkader Al Ghouz, Jeannine Bischoff, Sarah Dusend

\section{Volume 3}

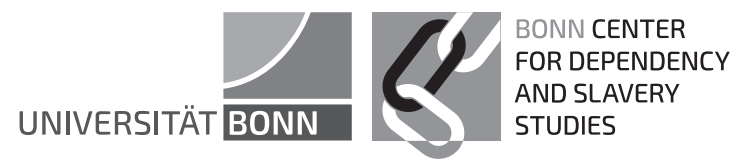




\author{
Caroline Laske
}

Medieval Women in the Très Ancien Coutumier de Normandie. Textual Representation of Asymmetrical Dependencies

\footnotetext{
ebv

BERLIN
}

EBVERLAG 
Bibliographic information published by the Deutsche Nationalbibliothek

The Deutsche Nationalbibliothek lists this publication in the Deutsche

Nationalbibliografie; detailed bibliographic data are available in the Internet at http://dnb.d-nb.de

Gefördert durch die Deutsche Forschungsgemeinschaft (DFG) im Rahmen der Exzellenzstrategie des Bundes und der Länder Exzellenzcluster Bonn Center for Dependency and Slavery Studies (BCDSS) EXC 2036/1-2020, Projektnummer: 390683433
All rights reserved. No part of this book may be reproduced in any form or by any electronic or mechanical means, including information storage and retrieval systems, without written permission from the publisher or author, except in the case of a reviewer, who may quote brief passages embodied in critical articles or in a review.

Funded by the Deutsche

Forschungsgemeinschaft (DFG, German

Research Foundation) under Germany's

Excellence Strategy - Cluster of Excellence

Bonn Center for Dependency and Slavery

Studies (BCDSS) EXC 2036/1-2020, Project No.: 390683433

\section{(C) $(1) \Theta$}

This work is licensed under the Creative Commons Attribution-NonCommercial-NoDerivatives 4.0 (BY-NC-ND) which means that the text may be used for non-commercial purposes, provided credit is given to the author. For details go to http://creativecommons.org/licenses/by-nc-nd/4.0/

To create an adaptation, translation, or derivative of the original work and for commercial use, further permission is required and can be obtained by contacting post@ebverlag.de

Creative Commons license terms for re-use do not apply to any content

(such as graphs, figures, photos, excerpts, etc.) not original to the Open Access publication and further permission may be required from the rights holder. The obligation to research and clear permission lies solely with the party re-using the material.

This book is available for free download in the Open Access section of the publishers' website. (https://doi.org/10.53179/9783868933963).

A print version is available for a fee from the publisher.

The page numbers in the print and in the online version are identical.

(C) EB-Verlag Dr. Brandt

Berlin, 2020

Coverdesign: (C) Rainer Kuhl, Berlin

ISBN 978-3-86893-358-1 (Print)

ISBN 978-3-86893-396-3 (Open Access)

DOI $10.53179 / 9783868933963$ 


\section{Medieval Women in the \\ Très Ancien Coutumier de Normandie. Textual Representation of Asymmetrical Dependencies*}

\section{Introduction}

Je sais que je suis l'esclave et vous le seigneur. La loi de ce pays vous a fait mon maître. Vous pouvez lier mon corps, garrotter mes mains, gouverner mes actions. Vous avez le droit du plus fort, et la société vous le confirme. ${ }^{1}$

That was the struggle of Indiana who tried to free herself from the enslavement and violence she experienced in her marriage. Set six centuries later than the thirteenth century customary law under discussion in this paper, George Sand tells the story of women unable to perceive their lives as separate from men. Despite the protagonist's insistence that her husband has no moral power over her, nor that he can manipulate her will, ${ }^{2}$ she is confronted with her condition of legal dependency every time she seeks independence. To free women from what Sand repeatedly described as an enslavement in marriage and generally in society, was an issue close to her heart. In her preface to the 1842 edition of Indiana, she muses that writing this novel was guided by a profound and legitimate revulsion "de l'injustice et de la barbarie des lois qui régissent encore

* This paper was researched and written during my Heinz Heinen Fellowship at the Bonn Center for Dependency and Slavery Studies. I would like to thank Dirk Heirbaut, Alain Wijffels, Els De Paermentier, Heather Tanner and Stefan Brink for their many helpful comments on earlier drafts of this paper. Any remaining errors are my own.

1 George Sand, Indiana (Paris: Éditions Gallimard, 1832/1984), 232. "I know that I am the slave and you are the master. The law of this country makes you my master. You can tie up my body, attach my hands, govern over my actions. You have the right of the strongest confirmed by society."

2 “...mais ma volonté, Monsieur, vous ne pouvez rien ... j’ai été respirer l'air de la liberté pour vous montrer que vous n'êtes pas moralement mon maître et que je dépends que de moi sur la terre." G. Sand (1832/1984), 232-233. 
l'existence de la femme dans le marriage, dans la famille et la société."3 Like her protagonist, Aurore Dudevant (alias George Sand) broke free from a marriage. Despite the property laws in force at the time, she managed to keep her fortune, and was hence able to mitigate that aspect of the asymmetrical dependency imposed by the legal and societal order in force in early nineteenth century France.

The issue of holding, managing and retaining property and legal capacity in relation to other matters has always been at the heart of women's agency, and is directly linked to the degree of the asymmetry in their dependencies, usually on male members of their family. The lack of legal status, legal capacity and legal competence are the quintessential expressions of women's asymmetrical dependency in society and in the eyes of the law. This is particularly poignant in relation to the capacity to hold land, dispose of property, run a business, appear in a court of law etc. The research reported in this paper aims to reveal the extent of that legal dependency in both real and rhetorical terms by studying the textual and semantic representation of women in a specific medieval Norman customary law text. It will allow us to go beyond the content analysis and get a better understanding of the actual experience of women's legal capacity and competence. An examination of the language used to express the normative reality concerning women at the time reveals the ways in which meanings - as linguistic expressions of reality - were encoded and, hence, how the experience of that reality is constructed through the experiential meanings in the texts. It provides a way of understanding the interaction between the way customs (and customary law) create meanings in language, and the way language creates realities in the normative construct of social experience. The study of not only the proportional textual presence of women and men but also of the categories of descriptios relating to women and to their activities/variety of roles in comparison to men gives us an insight into how they were represented and hence considered. If women are predominantly referred to in relation to their family set-up or marital status, but never according to anything that

3 George Sand (1832/1984), 46: “...of the injustice and barbarity of the laws that still govern the existence of women in wedlock, in the family and in society." 
may reveal socio-political or religious power of action and influence or professional activities, we can infer that the narrative in the Norman customary law does not invest women with a particularly varied normative reality and independence.

The paper is structured into five parts. The first section deals with the more general issues of studying medieval women's legal status, legal capacity and legal competence, including how these terms are defined and understood in this paper. The second part will discuss customary law in general and that of thirteenth century Normandy in particular. This is followed by an overview of the provisions relating to women in Norman customary law. The fourth section describes the textual and linguistic analysis of the Très Ancien Coutumier de Normandie allowing us to understand what the representational semantic aspect of language teaches us about the realities of women's legal status and capacity in the twelve and thirteenth centuries. The concluding part summarises the observations by comparing and contrasting the findings for the terms relating to women with equivalent terms that relate to men.

\section{Medieval women's legal status, legal capacity and legal competence}

It is important to define some of the terminology this paper will be using, as it tends to be understood differently depending on the reader's academic discipline and the culture/language context. The term agency has a very general sense and should be understood as it is used in social sciences and not according to its legal definition. Women's agency refers to their capacity and ability to act independently - in our context from social and legal constraints imposed in favour of their menfolk. The terms legal status, legal capacity and legal competence refer to specifically legal concepts. Legal status stands for all the rights and duties people have by virtue of their (legal) status. The possibility to act upon these rights and duties constitutes the legal capacity - can a woman act in law (an abstract question). It is defined, maybe more precisely, in 
the German concept of Rechtsfähigkeit. ${ }^{4}$ Legal competence, on the other hand, akin to the German concept of Handlungsfähigkeit, ${ }^{5}$ is the ability to actually use the rights and duties attributed by law or custom. Can a woman perform this specific legal act? This could include loopholes in the law or exceptions made for pragmatic reasons. In today's legal thinking, we see one feeding into and being interdependent on the other. This paper will mainly discuss women's legal capacity as reflected in the Très Ancien Coutumier de Normandie. For a complete picture of how legal capacity and legal competence interacted and played out in everyday life, it is necessary to also study the sources that reflect a law-in-action angle. This is beyond the scope of the present paper.

Women's legal status, capacity and competence were, as such, not defined in medieval customary law, as we would find in modern law. We infer these from a multitude of sources and provisions, including nonlegal sources, such as manuals that classify women into specific groups and prescribe dos and don'ts. Some may be worded quite categorically, in particular in relation to married women, amounting to a legal status that lacks legal capacity. ${ }^{6}$ Yet women could be sued and held responsible in both private and criminal law. While they had no legal capacity to partake in any form of government, pragmatics (absence of male heir) dictated that when they inherited fiefs involving powers of government, they could participate in or even head feudal assemblies etc. Today's definitions of legal status, capacity and competence are somewhat lost in the age of customary law, when little was said about general legal status; when references to specific situations were made in the customary law text but these were more akin to specific (rather than general) legal capacity than to legal status; and when pragmatics could override what was laid down in the customary law texts.

While the dichotomy between law-on-paper and law-in-action is prominent in our modern construct of law and legal theory, the inter-

$4 \quad$ Rechtsfähigkeit should be translated as the (legal) capacity to have rights and obligations.

$5 \quad$ Handlungsfähigkeit should be translated as the (legal) power to act.

6 Philippe de Beaumanoir, Coutumes de Beauvaisis (Paris: Alphonse Picard et Fils, 1899), Tome II, §1054. 
pretation and functioning of customary law was very different in the Middle Ages. Customary law was primarily based on customs rather than on law, and such customs were the fruit of general acceptance that was repeated over time and by the community at large. In other words, we are dealing less with hard and fast, non-negotiable rules that formed a consistent construct of rules, and more with something akin to guides where the ultimate outcome conditioned the application or non-application of rules, customs and laws. During the Middle Ages, customary rules and laws were primarily social tools that guided societies and relationships. To that extent, and in view of the absence of a coherent construct of laws, it follows that there was no consistent legal capacity of women as we would understand it in modern terms.

But the study of women during the High Middle Ages raises the preliminary question of whether there is the justification for a study specifically dedicated to the category of 'women'. After all, there are no equivalent studies of 'men', and women are not a minority as such, although women have sometimes been described collectively as a 'minority group' - an unfortunate term as its numerical nature is actually inappropriate in this context. It could be argued that a justification can be found in the way women were defined during the Middle Ages and according to criteria that were specific to them with no equivalence for men. The society of the twelve to the thirteenth centuries was markedly hierarchical and patriarchal, ${ }^{7}$ and social classes differed substantially from one another in terms of rights, economic circumstances and modes of living. Most medieval writers in their description of their societies categorised women separately. This may be in terms of their socio-economic categories: nuns, lay women, noble ladies, wealthy bourgeoises, poor country women, maidservants, whores etc. (e.g. separate chapters for each in manuals for preachers ${ }^{8}$ ); or according to their marital status: maidens, married women, widows etc. (e.g. separate chapters for each

7 Judith Bennett, Patriarchy and the Challenge of Feminism (Manchester: Manchester University Press, 2006).

8 De Eruditione Praedicatorum by the Dominical Humbert de Romans (13th c.). 
in manuals of conduct ${ }^{9}$ ). Classification was also made in relation to a woman's various familial, biological, psychological phases, such as virgin, beloved, bride, newly-married, pregnant; or to faults and sins specifically attributed to women. To that extent, medieval writers treated women as a distinct class, which in itself represents a justification for this study on women's legal status and capacity. The underlying issues relate to whether there is a condition or a set of rules/laws that apply to all women qua women, whether the categorisations of women bore their distinctive marks on the medieval customs and laws and, if so, to what extent that corresponds to the realities of women's everyday lives.

While specific laws, rules and restrictions apply to the various categories and subcategories of women as described above, a rule imposed on all women which is expressed or implied in canon law, in customary law, and in legal treatises, was to exclude them from what we call public law today, that is from exercising powers of government at any level (whether locally or of an entire kingdom). Women could not hold political office, serve as military commanders, judges, lawyers etc., were unable to fill any public office, participate in any institutions of government, manorial courts, municipal institutions, royal council, representative assemblies etc. Consequently, if women could not represent themselves nor partake in some sort of government, they found themselves in a situation of asymmetrical dependency par excellence. In canon law, this was based on a woman's secondary place in creation and on her guilt in relation to Original Sin. This is particularly relevant to the context of nuns. ${ }^{10}$ In secular law, women were perceived as imbecillitas sexus, justifying legal restrictions not only on the basis of light-mindedness but also on their limited intelligence and avarice. ${ }^{11}$ But pragmatics conditioned certain situations to allow women (admittedly only a very small minority) to partake in governance, namely when they inherited fiefs

9 Livre de Manières by Etienne Fourgères (1168-1178). A printed edition edited by F. Talbert can be found on https://archive.org/details/LeLivreDesManieres.

10 Shulamith Shahar, The Fourth Estate. A history of women in the Middle Ages (London: Methuen, 1983), 12, 22-64.

11 Coutumier d'Artois, (Paris: Alphonse Picard, 1883) 121; La Très ancienne Coutume de Bretagne (Rennes: J. Plihon et L. Hervé Rennes, 1896) 126, 186; Shulamith Shahar, The Fourth Estate. A history of women in the Middle Ages (London: Methuen, 1983), 12. 
involving powers of government. In those cases, it was possible for them to participate in feudal assemblies of their lords alongside other vassals, head feudal assemblies of their own vassals, and discuss or legislate political and economic issues. This is a prime example of how late twelve and thirteenth century laws were not as strictly implemented as they would be in the modern period. Instead, they should be considered as guiding principles, as "a cultural and social experience in the words" in the words of Tanner. ${ }^{12}$

As far as legal rights are concerned, women were frequently set apart or classified in a specific category within the judicial system, procedures, rules and (customary) law. Legal capacity was not necessarily ruled out through blanket bans, but was frequently expressed in specific restrictions, varying from region to region. Legal capacity and competence or the lack thereof could often be inferred from other sources. Women found themselves usually excluded from serving as judges or as advocates for themselves or for their children/family. ${ }^{13}$ Similarly, women could not testify in court, nor serve as jurors, as "the blood of a man shall not be tried by a woman." 14 As far as criminal law was concerned, women (whether married or unmarried) could only bring charges for bodily harm, rape and insult, or, as implied in article 54 of Magna Carta, for the murder of her husband. ${ }^{15}$ Here, pragmatics also dictated that women

12 Heather Tanner, "Women's Legal Capacity: Was The Thirteenth Century a Turning Point?" in Paradigm Shifts During the Global Middle Ages and the Renaissance, ed. Albrecht Classen (Turnhout: Brepols, 2019) 82.

13 Philippe de Beaumanoir, Coutumes de Beauvaisis, (Paris: Alphonse Picard et Fils, 1899), Tome II ,\$1287: "Il ne loit pas a fame a estre en office d'avocat pour autrui pour louier, mes sans louier puet ele parler pour soi, ou pour ses enfans, ou pour aucun de son lignage,mes que ce soit de l'autorit" de son baron, s'ele a baron." Tome I, §190; "Il est certaine chose que fames en subjection d'autrui, si comme en marriage ou en religion, ne pueent ne ne doivent prendre arbitrage seur eles. Mes celes qui son ten leur deliver poosté le pueent bien fere et render la sentence de l'arbitrage, tout soit ce que drois die que fames ne doivent pas render jugement; mes c'est a entendre des jugemens qui sont fete $n$ court de plet ordené; car jegement d'arbitres sont de volonté et de conssentement de parties, par lequel consentement les parties pueent fere de leur non juges leur juges.".

14 Britton (Oxford: Clarendon Press, 1865), Volume I, Book I, Chapter XXXII, 207: “de sicum saunc de homme ne peut, ne deit, estre tryé par femmes".

15 Nullus capiatur nec imprisonetur propter appellum femine de morte alcerius quam viri sui. No one shall be arrested or imprisoned on the appeal of a women, for the death of any person except her husband. 
did testify in certain cases and, hence, the court recognised their testimony. These cases were concerned with matters that related specifically to issues concerning women and in which a man could not effectively give evidence, e.g. separation from husband, rape, infanticide etc. Such evidence was collected by women who were specially appointed for that purpose. For example, in the Très Ancien Coutumier de Normandie, a girl could claim justice if she had been raped. But she had to be examined by women who would know if she had been raped: "la justice fera veoir la meschine e sa bleceure par preude[s] fames e leaus, qui sachen quenoistre se elle a esté prise a force." 16 Presumably that evidence was taken into account by those in charge of rendering justice. To that extent and in such specific cases, some women could be considered as witnesses. On occasion we can also find women among the witnesses of charters. ${ }^{17}$

Rape is the one issue where we can observe (customary) law texts to provide women with some (limited) legal capacity to act. Punishment for rape varied, the guilty man might be blinded, castrated, flogged or hanged, ${ }^{18}$ but in practice it often came down to a monetary fine, or the court pardoned the rapist if he agreed to marry the woman in question. ${ }^{19}$ Although women were able to press charges for rape, or file a complaint, such claims tended to be greeted with suspicion that she wanted to force marriage on the man, or that she had actually enjoyed the rape and should therefore not be allowed to press charges. According to the medieval understanding of women's sexual and physiological nature, she secreted a seed to enable her to conceive and, by analogy to men, this would only happen if she was sexually satisfied. Pregnancy as a result of the act of rape was, therefore, seen as evidence of enjoyment. ${ }^{20}$

16 Coutumiers de Normandie, Le Très Ancien Coutumier de Normandie, texte français et normand (Rouen/Paris: Lestringant/Picard, 1903), tome I, $2^{\mathrm{e}}$ partie, L,1, 37: "The court will arrange for the girl and her injury to be examined by respectable and trustworthy women who will know/recognise if she had been taken by force."

17 Frederick Pollock and Frederic Maitland The History of English Law before the Time of Edward I (Cambridge: CUP, 1968), Vol. I, Book II, Ch. II §11, 484-485.

18 For example: Philippe de Beaumanoir, Coutumes de Beauvaisis (Paris: Alphonse Picard et Fils, 1899), Tome I, §824, 429.

19 Frederick Pollock and Frederic Maitland The History of English Law before the Time of Edward I (Cambridge: CUP, 1968), Vol. II, Book II, Ch. VIII §2 at 490-491.

20 Shulamith Shahar The Fourth Estate. A history of women in the Middle Ages (London: Methuen,1983), 17. 
While women's legal capacity was limited and dependent on their marital status, they could be sued in the same way as men with no regard to their sexual or marital status. Shahar provides a comprehensive insight, based on court records, into the type of offences committed by women:

... women were sued in civil law in such matters as non-payment of debts, violation of contract, and the illicit brewing of ale. Weavers were charged with pawning or selling their customers' good raw silk and weaving the cloth from inferior materials. In the cities women were charged with excessive opulence of dress, forbidden by the town's sumptuary laws. In villages and towns alike, women were accused of abusive and blasphemous conduct, trespassing, and fist-fights with both men and women. They were charged with theft, heresy, witchcraft, arson, infanticide and murder. ${ }^{21}$

Any differences in penalties imposed on women in comparison to men for the same crimes often lay in the interpretation of whether the behaviour of the defendant was considered to constitute an offence. It is as such not possible to make definitive statements about generalised uniformity or specific differences. Taking adultery as an example, there was a tendency for the criteria that classified an extra-marital relation as adulterous to vary according to whether it involved a married woman or man. ${ }^{22}$ It was also determined by whether it constituted a scandalum (an act inviting divine wrath). A women's adultery always tended to be considered a scandalum, which was far less the case for a man. Women would also frequently be forced into a convent, a sanction that did not apply to men. Similarly for witchcraft, which carried the same

21 Shulamith Shahar (1983), 17-21.

22 Mariann Naessens, "Judicial Authorities' Views of Women's Roles in Late Medieval Flanders," in The Texture of Society: Medieval Women in the Southern Low Countries, eds. Ellen Kittell and Mary Suydam (New York: Palgrave Macmillan, 2004), 51-77: examines courts records relating to various sexual crimes, including adultery, brothel keeping and cross dressing. She observed that judges appear mostly concerned with the preservation of men's honour through the fidelity and subordination of women. 
penalty for both sexes of burning at the stake, far more women were ever charged than men. ${ }^{23}$

One element that was very specific to the classification of women in medieval customary law was their marital (and sexual) status. There is no equivalent categorisation for men. In legal terms this was expressed as the principle of the femme covert, which set married women apart and afforded them particularly weak legal capacity. In Bracton and Glanvil we read that a wife has to obey her husband in all that is not contrary to Divine Law. ${ }^{24}$ There is a general tolerance of a husband beating his wife or using other measures to punish or reform her behaviour. ${ }^{25}$ Some reports of cases show men were fined for having used excess force against their wives, ${ }^{26}$ though if a man could nurse his wife back to health after a beating, he was not said to have broken the law! ${ }^{27}$

The status of wife per se puts a woman under some kind of guardianship of her husband, and restricts her legal rights in certain matters. In contrast to her unmarried or widowed self and according to some customary law texts, the married status may well not allow her to enter into contracts, take a loan or file a private law claim without the consent of her husband. A textual example for such restriction can be found in Beaumanoir's Coutumes de Beauvaisis:

23 It is unclear why not more men were charged. Because they did not engage in such practices, because they were not caught/reported? Because their actions were not classified as amounting to witchcraft? ... Frederick Pollock and Frederic Maitland The History of English Law before the Time of Edward I (Cambridge: CUP, 1968), Vol. II, Book II, Ch. VII §2, 406.

25 Philippe de Beaumanoir, Coutumes de Beauvaisis (Paris: Alphonse Picard et Fils, 1899), Tome II, §1631, 334. See also Emma Hawkes, “The 'Reasonable' Laws of Domestic Violence in Late Medieval England," in Domestic Violence in Medieval Texts, eds. Eve Salisbury, Georgiana Donavin, Merrall Llewelyn Price (Gainesville: University Press of Florida 2002): 57-70; the author suggests that the concept of reason worked on three levels in regard to the law and domestic abuse: 1) rationality, a masculine characteristic, was regarded as the key issue, 2) husbands could discipline their wives 'reasonably', 3) women were alienated from courts because their irrationality made them inherently unreliable.

26 John Gilissen, "La femme dans l'ancien droit belge," Société Jean Bodin, vol. XII (1962), 290-291; Registre criminal de la Justice de St. Martin des Champs de Paris (Paris: Leon Willem, 1660-1674/1877), 143-144.

27 14C legal code of Aardenburg (Flanders), mentioned in Shulamith Shahar The Fourth Estate. A history of women in the Middle Ages (London: Methuen,1983), 90-91. 
... ce qui est convenancié pour la fame au mariage envers le mari, il convient qu'il soit tenu, quel que convenance la fame eust devant les espousailles ou après, et en quell que estat qu'ele fust, ou veve ou pucele, car puis qu'ele s'est autrui aliee par mariage, ele n'a nule poosté de soi de ses convenances acomplir sans la volenté de son mari. ${ }^{28}$

Much has been written about what constitutes this guardianship and even if that is the appropriate term to use, as it tends to be associated with minors. ${ }^{29}$ The thinking is that, despite the many parallels in the lack of agency, the relationship between spouses should be nuanced rather than equated to that of a guardian to a minor. The youth of children constitutes a de facto physical and intellectual incapacity to make certain decisions or to assume responsibilities. It is less straightforward to affirm this about women, especially when for pragmatic reasons some women are being given such responsibilities and powers of decision.

As described earlier and developed further in the second section below, to view such provisions as rigidly prescriptive legal rules and laws, structured into a coherent system as we would today, is to misunderstand the nature of customary law. Tanner ${ }^{30}$ argues for a paradigm shift in the understanding of married women's legal capacity by considering this concept as "rooted in the twelfth and early thirteenth century mentalité and customary practices rather than modern ones." 31 There is plenty of evidence that married women were able to undertake a number of legal transactions, even if only on a temporary basis while their menfolk were away on crusades, tied up with feudal duties or fight-

28 Philippe de Beaumanoir, Coutumes de Beauvaisis (Paris: Alphonse Picard et Fils, 1899), Tome II, §1054: “... what was covenanted on behalf of the woman on her marriage to the husband must be kept, independent of any covenants the woman had before or after her marriage and of her status, whether widow or virgin. Once she bound herself in marriage, she has no capacity/authority in her own right to covenant anything without the agreement/will of her husband."

29 Kittel suggest the use of 'procurator' (at least in the context of medieval Flanders): Ellen Kittell, "Guardianship over Women in Medieval Flanders: a Reappraisal," Journal of Social History, vol. 31, no. 4 (1998) 899, 902-903.

30 Heather Tanner, "Women's Legal Capacity: Was The Thirteenth Century a Turning Point?" in Paradigm Shifts During the Global Middle Ages and the Renaissance, ed. Albrecht Classen (Turnhout: Brepols, 2019) 81-98.

31 H. Tanner (2019) 83. 
ing wars. ${ }^{32}$ In fact, married women frequently represented the family unit and were engaged in public business, either on behalf of absent spouses or on their own behalf. The agency of women transacting business independent from their husbands is richly documented, for example, for medieval Flanders. ${ }^{33}$ Tanner $^{34}$ also describes how women, as landowners, were legally capable, how they could and did make legally valid transactions, how they represented themselves and their husbands in court and could be held legally responsible for their actions. She concludes that at least in thirteenth century France and England couverture was an administrative function rather than amounting to a loss of legal right. It allowed husbands to act as their wives' administrators, legal representative or procurators, to use Kittel's term for Flanders. It would be wrong to state that women had no legal capacity because some sources have shown that in specific situations, they were given specific legal capacities and competences. Nevertheless, it would equally be wrong to state that women had blanket legal capacity in the way we understand it today and based on their legal status, because this is not borne out in customary law texts. So, in the context of medieval customary law, we

32 Katherine Lewis, "Women, Testamentary Discourse and Life-Writing in Later Medieval England," in Medieval Women and the Law, ed. Noël Menuge (Woodbridge: The Boydell Press, 2000), 57-75; Victoria Thompson, "Women, Power and Protection in Tenthand Eleventh-Century England," in Medieval Women and the Law, ed. Noël Menuge (Woodbridge: The Boydell Press, 2000), 1-17; Ellen Kittell, "Guardianship over Women in Medieval Flanders: a reappraisal," Journal of Social History, vol. 31, no. 4 (1998), 897-930; Pauline Stafford, "Women and the Norman Conquest," Transactions of the Royal Historical Society, vol. 4 (1994) 221-249; Pauline Stafford, "Women in Domesday," Reading Medieval Studies, vol. 15, (1989) 75-94; Eleanor Searle, "Women and the Legitimisation of Succession," Proceedings of the Battle Conference on Anglo-Norman Studies, vol. 3 (1980) 159-170; John Gilissen 'Le statut de la femme dans l'ancien droit belge', in La femme, Recueils de la Société Jean Bodin pour l'histoire comparative des institutions (1958), Bruxelles, 255-321.

33 Ellen Kittell, "Guardianship over Women in Medieval Flanders: a reappraisal," Journal of Social History, vol. 31, no. 4 (1998), 897-930; Ellen Kittell "Testaments of two cities: A comparative analysis of the wills of medieval Genoa and Douai," European Review of History, 5:1 (1998) 47-82; Martha Howell, The marriage exchange : property, social place, and gender in cities of the Low Countries, 1300-1550 (Chicago: The University of Chicago Press, 1998); Shennan Hutton, Women and economic activities in Ghent (New York: Palgrave Macmillan, 2011).

34 Heather Tanner, "Women's Legal Capacity: Was The Thirteenth Century a Turning Point?" in Paradigm Shifts During the Global Middle Ages and the Renaissance, ed. Albrecht Classen (Turnhout: Brepols, 2019). 
can only talk about legal capacity if we define it in the sense that in limited cases, usually driven by pragmatics, women were given some legal capacity and competences but that was the exception rather than rule. Tanner is right in advocating that we should not see medieval wives' legal capacity through our contemporary prism of hard and fast legal prescription, but neither the concept nor the term of legal capacity go back to the Middle Ages. To stay true to the shift in paradigm, we need to emphasise that the use of the term and the concept is adopted with the understanding that customary laws are not absolute rules but guided, among others, by pragmatics.

A married woman's legal capacity was particularly curtailed in relation to property, including in many cases the property she brought into the marriage, though there were regional differences in the details of how property was handled in a marriage. ${ }^{35}$ Matrimonial property laws tended to be a mix between the Roman tradition, whereby the wife provided the dowry, and the Germanic custom according to which the husband paid bride-money, in particular in lesser marriages. In some regions, assets became joint upon marriage and during its duration. In other regions this was not so, or there were intermediate scenarios in which pre-marital assets would be excluded from becoming part of the joint property. The details of these arrangements became particularly relevant in the case of a separation. But for the duration of a marriage, immovable property and the income from assets would normally be considered as jointly shared. The husband was vested with very large powers over the entire mass of property, usually with the only limitation that he could not alienate his wife's property without her consent, which might amount to the assets she brought into the marriage or those she had inherited during the marriage or the dower that was promised by her spouse. The concept of 'community of goods' between spouses appeared in many European regions, though there were differences in what was considered to be included in the common stock:

35 Shulamith Shahar The Fourth Estate. A history of women in the Middle Ages (London: Methuen, 1983) 90-92. Interestingly, Sweden introduced a new law in the 1250s, whereby the daughter/sister should inherit the equivalent of half the property inherited by her brother. 
the whole property independent of whether it was acquired before or during marriage, or just what was added during the marriage, should it include movables as well as immovables etc. Fiefs were usually excluded from such customs and arrangements. From the point of view of legal theory, it is actually difficult to decide "who, when analysis has been carried to the uttermost, is really the owner of [this common stock]."36 In English law, and the closely-related law of Normandy, the concept of community of goods was rejected, which was remarkable in the case of Normandy, as the neighbouring rest of Northern France and medieval Flanders applied that concept. Pollock and Maitland ${ }^{37}$ offer some explanations as to why that appears to be the case. The absence of community, which for England also includes movables, means that the husband owns all property acquired during the marriage. He also manages his wife's property which she cannot alienate without his consent. In both England and Normandy, a widow has a right to one third of the land of which the husband was seised in fee during the course of the marriage. To that extent the husband cannot alienate his land in a way that would deprive his wife of her right of dower.

The issue of women's legal capacity and competence during the thirteenth and fourteenth centuries in northwest Europe is a vast subject and is conditioned by regional diversities (e.g. Normandy, England, Flanders), differences in social, financial and marital status (e.g. nobility, town women, landowning, married, widowed), and by the specific issues (e.g. landholding, inheritance, contracting business). ${ }^{38}$ It is impossible to discuss all angles in this paper, though many aspects have been examined by eminent scholars referenced in the footnotes and bibliography. In general, it can be said that medieval law, in particular in relation to married women, deprived them of legal capacity and competence and,

36 Frederick Pollock and Frederic Maitland The History of English Law before the Time of Edward I (Cambridge: CUP, 1968), Vol. II, Book II, Ch. VII §2, 401.

37 F. Pollock, F. Maitland (1968) Vol. II, Book II, Ch. VII §2, 402-403.

38 Tanner also argues that from the $14 \mathrm{C}$ the prescriptive texts were enforced more strictly and that it is therefore somewhat complicated to compare the 13C Norman coutumiers with the later 14C and 15C French and Flemish texts. Heather Tanner, "Women's Legal Capacity: Was The Thirteenth Century a Turning Point?" in Paradigm Shifts During the Global Middle Ages and the Renaissance, ed. Albrecht Classen (Turnhout: Brepols, 2019). 
hence, relegated them to a condition of asymmetrical dependency on their husbands. However, it is equally true to state that customary rules restricting women's legal capacity were circumvented when pragmatic considerations demanded a different outcome: “... lawmakers, jurists, and courts constantly renegotiated these very elaborate - but sometimes impractical or simply ignored - systems of law with respect to married women. We therefore need to be wary of seeing the law as something that evolves in a single direction, whether to married women's benefit or detriment." 39 During the fourteenth century, ${ }^{40}$ the more flexible and organic nature of the customary law was gradually eroded by increased political and administrative centralisation, by the professionalisation of the judicial system and by greater literacy. In other words, it lost some of its customary characteristics, especially with the rise of written court reports, such as the Year Books in England. The prescriptive aspect overrode the descriptive/guiding nature of customary law. The de facto legal capacity some women were able to exercise in the thirteenth and fourteenth centuries were overridden by de jure restrictions of their rights. ${ }^{41}$

With a view to follow some of what was said in this introductory part, the next section will discuss a specific customary law source, namely the Le Très Ancien Coutumier de Normandie. The aim is to examine how women were represented in that text and how that compared to the textual and semantic representation of men. Ultimately, this needs to be complemented with similar studies of other customary law compilations and (law-in-action) texts, such as court reports and private documents such as women's wills.

39 Cordelia Beattie \& Matthew Stevens, "Introduction: Uncovering Married Women," in Married Women and the Law in Premodern Northwest Europe, eds. C. Beattie \& M.F. Stevens, Gender in the Middle Ages 8 (Woodbridge: Boydell, 2013) 5.

40 A little earlier in the case of England. For the rather exceptional situation in medieval Flanders, see Dirk Heirbaut, "Who Were the Makers of Customary Law in Medieval Europe - Some Answers Based on Sources about the Spokesmen of Flemish Feudal Courts," Legal History Review, 75, 3, (2007) 257-274.

41 Heather Tanner, "Women's Legal Capacity: Was The Thirteenth Century a Turning Point?" in Paradigm Shifts During the Global Middle Ages and the Renaissance, ed. Albrecht Classen (Turnhout: Brepols, 2019) 97-98. 


\section{Customary law and the Le Très Ancien Coutumier de Normandie}

As discussed above, legal customs are primarily based on custom rather than on law, and such customs are the fruit of general acceptance that is repeated over time and by the community at large. They were usually grounded in oral traditions. ${ }^{42}$ After the end of Roman rule and under the influence of the Barbarian peoples, laws in written form were often displaced by symbolic gestures such as the handshake to seal a deal or the immixtio mannum that marked the dependence of a vassal on his master. But during the twelfth century, fixing laws in written form was once again on the rise, especially in relation to ecclesiastical law, e.g. cartularies of Mont-St-Michel. The thirteenth and fourteenth centuries then saw the appearances of a number of seminal customary law texts in several regions, such as the Sachsenspiegel, Coutumes de Beauvaisis, La Très Ancienne Coutume de Bretagne etc.

The main difference between laws and customs is that, although the latter formed a part of a body of jurisprudence, only the former were made by identifiable rulers. In eleventh and twelfth century Normandy, laws were written by the dukes, ${ }^{43}$ who were also kings of England; while customs were usually unwritten and agreed by the community. According to Hagger, ${ }^{44}$ medieval Normans did not consider law and customs as interchangeable terms. Instead, they saw them as referring to separate entities that could be brought together under the umbrella concept of an overarching ius, which may be conceived as something akin to norms that guide decisions in law suits. It is likely that educated Normans used Isidore of Seville's Etymologies 45 to increase their understanding of how to define law, customs and rights, which is reflected in some narrative

\footnotetext{
42 Marco Mostert and Paul Barnwell, eds., Medieval Legal Process. Physical, Spoken and Written Performances in the Middle Ages (Turnhout: Brepols, 2011).

43 Gilduin Davy, Le duc et la loi: héritages, images et expressions du pouvoir normatif dans le duché de Normandie, des origines à la mort du Conquérant: fin du IXe siècle - 1087 (Paris: De Boccard 2004).

44 Mark Hagger, "Secular Law and Customs in Ducal Normandy, c. 1000-1144," Speculum 85, (2010) 827.

45 Isidore of Seville, The Etymologies of Isidore of Seville (Cambridge: CUP, 2006).
} 
sources and in some acta but not in records of lawsuits. ${ }^{46}$ Seville sets out that "all jurisprudence (ius) consists of laws and customs. A law is a written statute. A custom is usage tested by age, or unwritten law, for law is named from reading because it is written." 47 It is likely that Norman monks and clerks had access to Roman law, not only through the Etymologies ${ }^{48}$ but also to the constituent works of the Corpus iuris civilis. ${ }^{49}$

During the eleventh and twelfth centuries, several initiatives to compile customs in written form lead to a number of customary law texts. But such inquests should be seen neither as lawmaking nor as anything akin to codification. From our twenty first century perspective we may perceive the act of writing down customs as bearing witness to an intention to create something new or established with some effect on future application and strength. But the Norman Consuetudines or Coutumiers were born from a desire to fix in writing a communal memory of customs, frequently in times of (geo)-political turmoil and to avoid conflicts and misinterpretation by certain social groups. At the very end of the eleventh century, ${ }^{50}$ the Consuetudines et iusticie was drawn up by the bishops and barons of Normandy, brought together from across the duchy to write down the shared memory of the existing customs that were accepted and repeated over time. As Hagger explains, this sort of work was done in Ireland and Wales by semi-professional lawmen, while in England it was carried out by the suitors of the shire court. ${ }^{51}$ These customs had materialised in the period after Rollo had been awarded Rouen.

The Norman customs of particular interest to this study were set out on paper in a series of documents that date from the end of the twelfth

\footnotetext{
46 Mark Hagger, "Secular Law and Customs in Ducal Normandy, c. 1000-1144," Speculum 85, (2010) 827.

47 Isidore of Seville, The Etymologies of Isidore of Seville (Cambridge: CUP, 2006) 5.3, at 117, also 2.10, at 73 .

48 Isidore of Seville, Book 5 and 2.

49 Mont-Saint-Michel had a late 11C copy of the Codex.

50 At Caen in 1091 (suggested by Charles Haskins, Norman Institutions (Cambridge: Harvard University Press, 1918), Appendix D, 277-284, at 278) or in 1096 (suggested by William Aird, Robert Curthose, Duke of Normandy [1050-1134] (Woodbridge: The Boydell Press 2008) at 163-164).

51 Mark Hagger, "Secular Law and Customs in Ducal Normandy, c. 1000-1144," Speculum 85, (2010) 851.
} 
and beginning of the thirteenth centuries, and all were the result of private initiatives in times of geo-political upheaval. Of the two texts that make up the Très Ancien Coutumier de Normandie, ${ }^{52}$ one dates before and one after the conquest of Normandy by Philip Augustus; there was an interval of roughly two decades between them. Although linked to the ambitions of the French king of controlling Normandy, both texts were the result of private initiative without Philip Augustus having a hand in it. The first of the two texts was written in Latin by a clerk of Evreux during the troubled times of the last decades of the twelve century. The king of France was, since his 1180 accession to the throne, determined to reduce the de facto power of the vast Plantagenet territories that spread over approximately half of his kingdom. He supported Richard in the rebellion against his father Henry II, then John in his attempts to obtain power during Richard's captivity, gaining finally control of the county of Évreux and the Norman Vexin, following his negotiations with King John in May 1200. It is during the turmoil immediately preceding the agreement between Philip Augustus and King John, when there was much uncertainty as to how the traditional Norman customs would fare under French rule, that a clerk at Évreux took it upon himself to fix in writing the customary law of Normandy.

The second text was written sometime between 1218 and 1223 in similarly troubled times, as Philippe August set out to conquer the rest of Normandy. Rouen fell in 1204 and consequently the whole duchy came under the control of the French crown. For the Norman elite this meant that they would have to switch their allegiance from the English to the French king, and many saw some of their land confiscated. While the judicial institutions remained intact, Norman local officials were replaced by men from the Île-de-France and it was becoming increasingly obvious that Normandy would be integrated into the French king-

52 The printed edition used for the purpose of this study were edited by E-J Tardif: Coutumiers de Normandie, ed. E.J. Tardif, 2 tomes, 3 volumes; tome I, $1^{\text {ère }}$ partie, Le Très Ancien Coutumier de Normandie, texte latin (Rouen: Cagniard, 1881); tome I, $2^{\mathrm{e}}$ partie, Le Très Ancien Coutumier de Normandie, texte français et normand (Rouen/Paris: Lestringant/Picard, 1903); tome II, La Summa de legibus Normannie in curia laicali (Rouen/ Paris: Lestringant/Picard, 1896). 
dom. Another clerk, this time from Bayeux or Bessin, set out to complete the first text of 1200 by writing a second coutumier.

Between 1235 and 1258, a third customary law text saw the light: the Summa de legibus Normanniae in curia laïcali was written in a very different context from the two texts of the Très Ancien Coutumier. With a view to preparing himself spiritually for the forthcoming crusade, Louis IX had ordered an inquiry (1247) into the abuses committed against the Normans during the time of the conquest by the French. Approximately four decades had passed, so it was the testimonies and complaints of the descendants relating to the injustices that were collected and brought together in a text known as Querimoniae Normannorum. ${ }^{53}$ This process allowed for an impression among the Norman people that they were heard and maybe understood by the French crown, which was an important element for more reconciliatory relations with the Capetian dynasty. ${ }^{54}$ On his return from the crusade King Louis IX, Louis the Saint, brokered a peace treaty (1258) with Henry III, which ushered in an eighty-year period of peace with England. It is in this context of Saint Louis' reign and also of the generally vibrant intellectual environment of the mid-thirteenth century France that a clerk from Cotentin (diocese of Coutances) wrote the Summa de legibus. ${ }^{55}$ Neveux places this text among the treatises that saw the light at that time, such as the Speculum doctrinale, historiale et naturale of Beauvais, Aquinas' Summa Theologiae. ${ }^{56}$

At the end of the thirteenth century the Summa de legibus was translated into French and became the Grand Coutumier de Normandie. The translation into the vernacular rendered Norman customary law more widely accessible to those who did not master Latin. Together with the Charte aux Normands, conceding privileges to Normandy by Louis X in 1315, the Grand Coutumier came to be regarded as an official text, even

53 Querimoniae Normannorum, Recueil des historiens des Gaules et de la France, tome XXIV (Paris: Imprimerie nationale, 1904) 1-73.

54 François Neveux, "Le contexte historique de la rédaction des coutumiers normands," Annales de Normandie, 2011/2, 19.

55 Neveux points out that Tardif had chosen this title for his 1896 edition. Yet during the Middle Ages the text was better known as Jura et consuetudines Normanniae, see François Neveux, "Le contexte historique de la rédaction des coutumiers normands," Annales de Normandie, 2011/2, 21, footnote 45.

56 F. Neveux (2011) at 21. 
though it had never received official royal approval. Although Normandy had been precocious in setting out its customs in writing, it was one of the last among the French provinces to write up an official version of its customary law in 1583, which was confusingly called Coutume reformée.

There are several manuscripts in which we can find the texts of the Latin or French versions of the Norman customary law, as well as much other material such as collection of judgements of the exchequer, or decisions given by the assises. Tardif gives an excellent overview of the various manuscripts, texts and previous editions (Warnkoenig, Marnier etc.) that were the basis of his own edition. ${ }^{57}$ The details will not be repeated here. The text used for this study is a French translation of the Très Ancien Coutumier, the only manuscript version of which can be found in Paris at the Bibliothèque Sainte-Geneviève. The manuscript is made up of 158 vellum sheets, of $228 \mathrm{~mm}$ by $159 \mathrm{~mm}$. Unfortunately, damage to the manuscript has meant that a number of pages are missing. Most notably the very first pages were torn out, probably for the value of their miniatures and illuminations. The writing is set out in two columns and is entirely by the same hand, but there are no indications as to precise dating. Tardif contends that the linguistic and palaeographical analysis have shown this transcription was made around the year $1290 .{ }^{58}$ The question of which version predates the other - the Latin or the French - can only be answered on a presumptive basis. During the thirteenth century, it was still the general custom for legal texts to be written in Latin. All Anglo-Norman treatises of the twelfth and thirteenth centuries were in Latin, with the exception of Britton. ${ }^{59}$ This is also the case of coutumiers contemporaneous with the Très Ancien Coutumier de Normandie. Moreover, there are numerous examples for the thirteenth and fourteenth centuries of texts translated from Latin into the vernacular, and yet none for the translation process having gone the other direction. There are a few discrepancies between the two texts, ${ }^{60}$

57 E.J. Tardif (ed.) tome I, $1^{\text {ère }}$ partie (1881): Introduction, $\mathrm{v}-\mathrm{xciv}$; tome $\mathrm{I}, 2^{\mathrm{e}}$ partie (1903): Introduction, i - xcix; tome II (1896) Introduction, i - ccxlvii.

58 E.J. Tardif (ed.) tome I, 1 ère partie (1881): Introduction, v - xciv, at xxix.

59 Britton (Oxford: Clarendon Press 1865).

60 Tardif makes a detailed analysis of the similarities and differences between the two 
but otherwise the French version reproduces almost slavishly the Latin text, to a point of sometimes transposing the same word order into the vernacular. However, at times the French version can be more precise than the Latin text.

The translation of legal texts into the vernacular, as we have seen in thirteenth century Normandy, as well as elsewhere, made these texts more accessible to a readership who had insufficient or no command of Latin. But translating these long established customs into an everyday idiom also paves the way for conceptualising the customary rules and laws in an everyday idiom. To the extent that customary law is not a collection of physically verifiable 'natural facts' ${ }^{\prime 61}$ but rather a phenomenon created by man, without existing as such in the material world, the language used to describe this phenomenon is intrinsically linked to its specific reality. By encoding our experience of the world in the language we use to describe it, the representational aspect of language conveys a multi-dimensional picture of reality, as we tease out the underlying socio-political and cultural aspects. With these multidimensional aspects in mind, to study how normative power was encoded in customary law from both a linguistic and content approach is also to gain a better understanding of the extent and nature of women's legal status and capacity. In the choice of text, priority was given to vernacular language sources, as these are more likely to reflect the pragmatic approach of language in use.

\section{Provisions relating to women in Norman customary law}

Most of the provisions relating to women in the Coutumier are concerned with rules of inheritance and dower. Norman customary law very much followed the tradition that strictly excluded women from inheriting land,

texts in the introduction to the French edition: E.J. Tardif (ed.) tome I, $2^{\mathrm{e}}$ partie (1903): Introduction, i - xcix, at xvi-xxxiii.

61 Neil MacCormick and Ota Weinberger, An Institutional Theory of Law (Dordrecht: Kluwer 1986), chapter 3, by analogy to Searle's conception of law as 'institutional fact' (John Searle, The Social Construction of Reality (London: Allen Lane 1995) 46. See also Caroline Laske, Law, Language and Change (Leiden: Brill Nijhoff, 2020) 9. 
on the basis that land was the property of the family and should not be removed by women marrying into another family. While in Italy the Libri feudorum excludes women from inheriting a fief in the twelfth century, this cannot be said for other regions. In the Duchy of Bourgogne women succeeded to fiefs on two occasions in the tenth century, in the County of Marche and of Carcassonne twice during the eleventh century and, of course, in Aquitaine in 1137 when Eleanor became Duchess of Aquitaine in her own right, adding the Duchy to the Anglo-Norman territories on her marriage with King Henry II of England. When the exclusion of women is not being adhered to strictly, it is of interest to examine two possible scenarios: daughters inheriting (a) when there are brothers, and (b) in the absence of brothers. In cases when a father leaves daughters as well as sons, Norman customary law usually applies the priority rule that the son(s) will inherit to the exclusion of the daughters. Orderic Vitalis tells of several stories from the eleventh century which leave no doubt that daughters were left empty-handed, and in cases of primogeniture, so were all sons who were not first-born. ${ }^{62}$ During the thirteenth century (maybe a little earlier) it was thought important to ensure daughters were left in a more comfortable material position. This was achieved either during the life time of the father, or after his death, in which case the daughter needs to address her claim to her brother. Either way, while she was not owed any pecuniary advantages by either her father or brother, there was an absolute duty to arrange a marriage for her. ${ }^{63}$ This could include a dowry but it was not an obligation. However, if the father promised a dowry he was bound by that promise, though he could not earmark more than a third of his property for his daughters. ${ }^{64}$ It was,

62 Orderic Vitalis, III, V t.II \& VIII, XXVIII, t. III.

63 "Nulla vero mulier contra fratres suos vel eorum heredes aliquid ratione hereditatis potest reclamare, nisi id solummodo quod ei ad eam maritandam datum fuerit vel concessum, prout per recordationem maritagii probatum fuerit evidenter. Et si ei nihil datum fuerit, nulla ultra ratione hereditatis aliquid poteris reclamare contra fratres suos vel eorum heredes, contra sorores tamen erunt semper equales", Coutumiers de Normandie, E.J. Tardif (ed.) 2 tomes, 3 volumes, t. II, La Summa de legibus Normannie in curia laicali (Rouen/Paris: Lestringant/Picard, 1896) Capitulum C./ 11 at 249.

64 La Summa de legibus Normanniae in curia laicali, Capitulum XXIV, 14, at 83. 
however, possible for a mother ${ }^{65}$ even when widowed, ${ }^{66}$ to provide a dowry for her daughter. If a daughter was not married at the time of her father's death, it was the brother's duty to find her a husband of her rank and social standing - in genere et in tenement - except if she had behaved badly. ${ }^{67} \mathrm{He}$ could but was not obliged to provide a dowry for her. The brother could also settle from the inherited estate for his sister's future marriage, though this amounted in no way to a right of inheritance on her part. ${ }^{68}$ If the brother failed to find a husband of the same social rank and fortune, she could make a complaint against him, a possibility she did not have against her father. This procedure required the brother to comply with finding a suitable husband for his sister within a year and one day, though the actual marriage could take place later. If the brother still failed or refused to comply with his obligation, the court will allocate to her a third (or her part of the third) of the father's estate. ${ }^{69} \mathrm{In}$

65 "Judicatum est quod Radulfus, filius Hugonis de Haia, non erat desaisiatus de maritagio quod mater uxoris sue dedit eidem Radulfo cum filia sua quando ipsam duxit in uxorem, donec Th[omas] de Sancto Egidio, frater uxoris ejusdem Radulfi, faciat eidem Radulfo competens maritagium, [cum] illud non fuerit factum assensu ejusdem Th[ome], qui est infra etatem, et cum non sit de hereditate partis sui." $\mathrm{N}^{\circ} 225$, Recueil de Jugements de l'Echiquier de Normandie, ed. Léopold Delisle (Paris: Imprimerie impériale) 57.

66 "Judicatum est quod mulier vidua potest dare terciam partem hereditatis sue cuicunque voluerit, vel trader in vadimonium ad maritandam filiam suam, si ei placuerit, ad valorem tercie partis." $\mathrm{N}^{\circ}$ 519, Recueil de Jugements de l'Echiquier de Normandie, ed. Léopold Delisle (Paris: Imprimerie impériale) 122.

67 "Se aucuns oirs a une suer, il la mariera de sa partie de la terre som pere ou de son chattel a son pooir regnablement e em parage e en tenement, se elle ne le forfet par vivre malvèsement e luxurieusment.", Coutumiers de Normandie, ed. E.J. Tardif, 2 tomes, 3 volumes, t. I, $2^{\mathrm{e}}$ partie, Le Très Ancien Coutumier de Normandie, texte français et normand (Rouen/Paris: Lestringant/Picard, 1903) Chapitre X, 1, 9.

68 "Sorores autem in hereditate patris nullam portionem debent reclamare versus fratres vel eorum heredes, sed maritagium possunt requirere. Et si fratres eas ex mobili sine terra vel cum terra, vel ex terra sine mobili, voluerint maritare viris eis idoneis sine disparatione, hoc eisdem debet sufficere...", Coutumiers de Normandie, ed. E.J. Tardif, 2 tomes, 3 volumes, tome II, La Summa de legibus Normannie in curia laicali (Rouen/Paris: Lestringant/ Picard, 1896) Capitulum XXIV, 14, 83.

69 "Quant la suer vient a aage de marier, se ses freres ou ses cousins, o qui elle part a l'eritage, ne la veut porveoir avenantment de mariage, e elle se plaint de lui e elle [le] fet semondre en la cort le roi, il avra terme, $j$. an e un jor, a porveoir la dedanz ce de mariage selonc sa condition e selonc son tenement, e a maintenir la dedanz ce selonc son pooir. E se il ne le fet, des lors doit a justice le roi acomplir sa defaute e assigner a la suer, se elle est seule, la tierce partie de l'eritage ou sa part del tierz, se ill i a plus que lui, e lors se puet elle marier a qui que elle voudra.", Coutumiers de Normandie, ed. E.J. Tardif, 2 tomes, 3 volumes, tome 
cases where women did not stand in a direct but rather a collateral line of succession (though still from a common ancestor), they and their descendants were excluded from the inheritance (incl. land, chattels and acquisitions) by the male members and their descendants. ${ }^{70}$

The details of what exactly was included when daughters inherited and how the third of the inheritance was calculated to which some daughters had a claim, are elaborate and will not be discussed here. ${ }^{71}$ In general, it can be said that in the customary law of Normandy the exclusion of a daughter and her heirs (including her sons) from her father's inheritance applies. But with a view of some minimum protection for them, the rules recognised some limited right in specific situations, in particular that she should be found a husband of her social standing and fortune. If, due to the non-compliance of her brother, she had to take her claim to a court of justice, it would afford her a real part in her father's succession.

However, the situation differed if the father left daughters but no sons. During a time when in most French customary laws, women could be heirs, in Normandy this was only the case in the absence of a male heir. In this case, the rule to exclude women was no longer absolute in Norman customary law. The way the inherited property was divided amongst daughters differed when there were no male heirs, as the prime raison d'être for the primogeniture rules, namely to keep the property within the family was no longer relevant. However, if a fief was involved, the homage and duties concerned could be fulfilled by a daughter, or

I, $2^{\mathrm{e}}$ partie, Le Très Ancien Coutumier de Normandie, texte français et normand (Rouen/ Paris: Lestringant/Picard, 1903) Chapitre LXXX, 3, 70.

70 Coutumiers de Normandie, ed. E.J. Tardif, 2 tomes, 3 volumes, tome II, La Summa de legibus Normannie in curia laicali (Rouen/Paris: Lestringant/Picard, 1896) Chapitre XXIII, 11, 78; “Judicatum est quod Robertus de Fonteneto et frater suus et nepos eorum habeant saisinam suam de portionibus suis, et postea si domina de Fonteneto, neptis sua, voluerit de ipsis conqueri, poterit, et currat jus inter eos.»; $\mathrm{N}^{\circ} 650$, Recueil de Jugements de l'Echiquier de Normandie, ed. L. Delisle (Paris: Imprimerie impériale), 144; "Judicatum est quod Robertus de Fontibus et fratres ejus et nepos eorum habeant saisinam suam de portionibus suis et hominagiis suis, et quod ipsi non respondeant versus neptem suam." $\mathrm{N}^{\circ}$ 670, Recueil de Jugements de l'Echiquier de Normandie, ed. L. Delisle (Paris: Imprimerie impériale), 148.

71 R. Besnier (1930) Les Filles dans le droit successoral normand, Legal History Review/ Tijdschrift voor Rechtsgeschiedenis, vol.10, n², 498-500, 501-505. 
more likely by her husband. ${ }^{72}$ When the feudal system gradually weakened in the fourteenth and fifteenth centuries, this window of opportunity of limited rights of inheritance of a fief afforded to women, also closed.

It is significant, and this will be shown in more detail in the next section, that textual references to women in the Coutumier relate mainly to matters of inheritance, dower, marriage and family. These circumstances apparently specific to the situation of women are also presented as situations in which they are relatively passive: inheritance, dower, marriage are arranged for them rather than by them, and as a customary duty to them, rather than as a right for them to claim.

\section{Corpus Linguistics Analysis of Le Très Ancien Coutumier de Normandie}

For the purpose of this corpus linguistic study only the text of the SaintGeneviève manuscript was used as printed in the Tardif edition of the French text of the Très Ancien Coutumier. The fragments of the abridged version included in this particular edition were discarded when constituting the corpus. Also discarded were the editor's footnotes and the appendix De Patronage d'Iglise. The text obtained was reformatted so it can be read by the concordance software AntConc ${ }^{73}$ which is fully Unicode compliant, meaning that it can handle data in any language. However, the diversity in medieval spelling or grammatical forms could not be fully smoothed over by the software, although it allows for the possibility of wildcard searches, which are especially helpful in locating variations of a particular word. This meant that certain search functions

72 This is also reflected in Ranulf de Glanvill (12th c./1604) Tractatus de Legibus \& Consuetudinibus Regni Angliae, www.heinonline.org, Liber VII, Cap. 3 at 48.

73 AntConc is a concordance program developed by Laurence Anthony, Director of the Centre of English Language Education at Waseda University in Japan. There are versions available for Windows, Mac and Linux. The particular version used for this research is: AntConc 3.5.8m (2019). The program can be downloaded at the following page, which also includes links to online guides and video tutorials: http://www. antlab.sci.waseda.ac.jp/antconc_index.html. 
had to be carried out several times, once for each spelling variation, which could be as much as a dozen times for each search term. Proximity searches could become exponential because every spelling variant of every term had to be tried in combination. At times this issue can be overcome by wildcard searches, which allow for a special character, usually an asterisk, to replace one or more characters at the beginning or end of a search term. This is, however, not always appropriate nor did it always deliver satisfactory results.

AntConc allows us to create word lists and search the text files for words, phrases and patterns, though not all the tools it offers are relevant to this study. Once the corpus has been uploaded into the software, we obtain the information that the corpus contains 18,138 number of words (word tokens) and 2,213 number of unique word forms (word types) as opposed to total numbers. It is important to stress that the statistics for the word types/tokens may be skewed by the medieval spelling variations as the software does not recognise two different spellings of the same word as one word token. The study, therefore, did not include any discussion on type-token ratios for the corpus.

From the word list established by AntConc, we can observe there to be 10 categories of descriptios of women from among a total of 215 occurrences. This involves she, woman, sister, daughter, mother, widow, girl, eldest, virgin, cousin. ${ }^{74}$ In contrast, there are 21 categories of descriptios $^{75}$ for men, totalling 1154 occurrences for a greater variety of terms than used to describe women. From these figures alone we can observe that the male voice is far more predominant than the one relating to women. The pronoun ' $i l$ ' is ranked second on the word list with 601 hits. Although on occasions, these may not relate to a male descriptio, but rather to the neutral scenario of e.g. 'it has been said' (Il a esté dit devant generalment qe ... Chapitre LVII), the occurrence of this pronoun (331 per 10,000 words) occurs approximately eight times as frequently as its

74 The terms are: elle/elles; fame/fames; suer/suers; fille/filles; mere/mère; mechine/ meschine; vueve/vueves; ainznee; pucelle; cousine.

75 The terms are: il; homes/home/homs/hom/hommes/homme/omme; segneur/segneurs/ seigneur; chevalier/chevalier; sire; freres/frer/frères/; peres/pere/père; filz/fill/fil; mari/ mariz; senechau/senechal; sergent; baron/barons; arcevesque/arcevesques; ainznez/ainzné; borjoir; prestress; cousins/cosins/cousin; neveu. 
female counterpart (44 per 10,000 words), which is ranked 39 with 70 hits and its plural form - elles - with 10 hits on rank 244. The contrast is less striking for the generic descriptio woman - man. We have 63 hits for fame/fames, which represents 35 per 10,000 words, and 107 hits for homme ${ }^{76}$ in its various spellings, which is 59 occurrences per 10,000 words.

However, it is interesting to observe that there is a greater variety of categories of descriptios for men than for women. In other words, not only is there a considerably greater presence of the male voice in the text, but it also reveals that men have a greater variety of roles. The references to women are always in their relation to the family set-up or their marital status: women are sisters, mothers, daughters, cousins, widows or virgins, 9 categories in all. Their social status is revealed through their family and marital status, never through descriptios revealing anything in relation to other kinds of status, such as power, possession, professional activity etc. Terms that express some kind of female lordship or hierarchy, such as dame, domina, are entirely absent from the text. Men, on the other hand, are identified in relation to a number of roles (12 categories). Beside the family relation descriptios such as father, brother, son, husband etc. (8 categories), men are listed in relation to socio-political and religious power, such as king, earl or knight, (arch) bishop, priest, seneschal etc. In other words, the narrative told of men in Le très ancien coutumier de Normandie, is not only more substantial but also considerably more varied and thus contextually richer.

The text was searched more specifically for terms that are likely linguistic expressions of women's (legal) positions or would reveal such positions. In the case of some keywords these results were compared to equivalent terms for men. The descriptios can roughly be classified into three main groups moving from the central to the peripheral. At the centre the terms and language relate to

(a) the woman as her own person: e.g. she, woman. It then moves to

76 homes/home/homs/hom/hommes/homme/omme. 
(b) the definition of herself in relation to others: e.g. sister, daughter, mother, eldest, cousin etc.

On the more peripheral level, we find language that relate to her

(c) legal/marital/sexual status: e.g. widow, virgin etc. Also included in this category are terms that are commonly found in the context of women's property rights, such as e.g. dower, inheritance etc.

\section{1 'Elle/elles'}

The personal pronoun elle in its singular and plural form occurred 80 times ${ }^{77}$ in the Coutumier, which represents 44 times per 10,000 words. The first five nouns with which elle* collocates are: woman, dower, land, husband and force, ${ }^{78}$ and the first three verbs: to be, can and have. ${ }^{79}$ The results of the cluster tool show these words to be similarly prominent. When considering the specific $\mathrm{KWIC}^{80}$ lines, in particular those of the collocates, we can observe that the language surrounding the search term is not very rich and the contextual (factual) situations do not show great variety. Women are mentioned in relation to their husband, their dower or landholdings. The verbal groups with which they are associated - headed by to be, have, can - are among the most commonly occurring verbs. While this in itself is not very significant, it is interesting to note that the type of process indicated by both the central verbal elements as well as the surrounding language tend to relate to existential and relational processes that construe existence, relationships or identification. This reflects a more passive rather than an active aspect of the experiential world.

Besides the keyword search and KWIC display function, AntConc also offers the possibility of an 'advanced search' with more complex

elle: 70 hits; elles: 10 hits.

fame, doere, terre, mari, force.

est, puet, avoir.

80 Key-Word-In-Context is a pre-set format, which is the most common way to show concordance lines. KWIC places the search term in its context as found in the original text. These can then be sorted according to the words to the left and right of the search term and, hence, provide an excellent overview of the type of contexts in which the search terms occur. 
possibilities. It enables the search of KWIC lines with a second search term or set of search terms, either by typing them in one per line, or by uploading a list of search terms from another file. It is further possible to define the parameters for the context words and a word span which within the second (set of) search term(s) must appear. The word span adopted for this research is 10 words to the left and 10 words to the right of the main search term - 'elle' in this instance. If, in our example, we find the word 'terre' to appear significantly more often than the word 'église', we may conclude that women are more frequently mentioned in a context of land holding than in that of church matters. The choice of secondary search term(s) to be used in specific advanced searches was guided by the rankings in the corpus' word list. All identified spelling variations (including the plural form) were used and compounded in the statistical data.

\begin{tabular}{|l|r|r|r|r|r|}
\hline $\begin{array}{l}\text { search } \\
\text { term }\end{array}$ & \multicolumn{1}{|c|}{$\begin{array}{c}\text { hits } \\
(=\mathrm{N})\end{array}$} & $\begin{array}{c}\text { rel. freq. } \\
(10,000 \\
\text { words })\end{array}$ & $\begin{array}{c}\text { proximity } \\
\text { occurrences } \\
(=\mathrm{P})\end{array}$ & $\begin{array}{c}\text { relative } \\
\text { proximity } \\
(=\mathrm{P} / \mathrm{N})\end{array}$ & $\begin{array}{c}\text { prox. to } \\
\text { 'elle } \\
\left(=\mathrm{P} / \mathrm{N}_{0}\right)\end{array}$ \\
\hline elle & $\mathbf{8 0}\left(=\mathrm{N}_{0}\right)$ & $\mathbf{4 4}$ & $\mathbf{N} / \mathbf{A}$ & $\mathbf{N} / \mathbf{A}$ & $\mathbf{N} / \mathbf{A}$ \\
\hline terre & 129 & 71 & 13 & $10 \%$ & $16 \%$ \\
\hline homme & 107 & 59 & 2 & $2 \%$ & $3 \%$ \\
\hline héritage & 74 & 41 & 6 & $8 \%$ & $8 \%$ \\
\hline fame & 63 & 35 & 19 & $30 \%$ & $24 \%$ \\
\hline doere & 37 & 20 & 11 & $30 \%$ & $14 \%$ \\
\hline tierz & 27 & 15 & 6 & $22 \%$ & $8 \%$ \\
\hline mariage & 26 & 14 & 5 & $19 \%$ & $6 \%$ \\
\hline suer & 29 & 16 & 3 & $10 \%$ & $4 \%$ \\
\hline fille & 14 & 8 & 1 & $7 \%$ & $1 \%$ \\
\hline mère & 12 & 7 & 1 & $8 \%$ & $1 \%$ \\
\hline vueve & 7 & 4 & 5 & $6 \%$ & $71 \%$ \\
\hline mechine & 5 & 3 & 3 & $4 \%$ & $60 \%$ \\
\hline
\end{tabular}

Table 1: search terms/proximity to elle in Le très ancien coutumier de Normandie 
The template for the table above has been used throughout the statistical analysis for this study. The second and third columns give the absolute $(\mathrm{N})$ and relative frequencies with which each term occurs in the Coutumier. The subsequent three columns provide information on the proximity of some secondary terms to the primary term, which is elle in the table above. The fourth column (P) shows the number of times the secondary terms occurs in a proximity of ten words to the right and to the left of the primary search term. The fifth column $\left(\mathrm{P} / \mathrm{N}_{0}\right)$ expresses that frequency of proximity $(\mathrm{P})$ in relation to the number of occurrences of the primary term $\left(\mathrm{N}_{0}\right)$. For the last column the frequency of proximity of the secondary term (P) is calculated in relation to its own absolute frequency $(\mathrm{N})$. For example, in the table above elle occurs 80 times and terre 129 times. On 13 occasions, terre is within ten words of elle, which represents $16 \%$ of the 80 occurrences of elle $\left(\mathrm{P} / \mathrm{N}_{0}\right)$ and $10 \%$ of the 129 occurrences of terre $(\mathrm{P} / \mathrm{N})$.

For a generic term like fame to be quite prominent in the vicinity of the female pronoun elle is not surprising, but the same cannot be said for suer, fille or mère, all of which not only show low relative frequencies, but also low proximity data to elle. The term vueve is an interesting exception, though the figures must be taken with a pinch of salt to the extent that relative frequency of the word is very low. In $71 \%$ of the occurrence of the term it can be found in the vicinity of elle, while in only $6 \%$ of the occurrence of elle is vueve mentioned within ten words. This highlights a tendency for women to be described in generic terms (fame, elle) rather than by using more specific and varied descriptios, for example in relation to their social status. Besides these descriptios, the term that stands out in the results of the advanced proximity search is doere, and to some extent marriage and tierz. All are related to a woman's marital status and her property rights resulting from marriage/inheritance. This is reflected in the use of the term doere. In the advanced proximity search for elle we find it occurs 11 times, which represents $30 \%$ of its total occurrence and $14 \%$ of the occurrence of elle. These figures are relatively high in view of the fact that doere has a low relative frequency of 20 per 10,000 words for the whole corpus. Both marriage and tierz, with even lower relative frequencies (14 and 15 respectively) show a high percentage of occur- 
rences (19\% and $22 \%$ ) in the vicinity of elle. However, the term heritage only appears in $8 \%$ of its occurrences in the vicinity of elle, and terre in only $10 \%$ of its occurrences.

When examining closely the 80 KWIC lines for the occurrence of elle, we can study the surrounding language and context in greater detail. The experiential function of the language can be mapped from the central to the peripheral by considering at the centre the verbal group as process, then the participants in the process in form of the nominal group and finally the circumstances surrounding the process expressed in prepositional phrases, adverbial groups and some secondary nominal groups. As far as processes directly related to elle are concerned, we find 208 verbal groups. In 37\% these verbs are so-called 'doing' verbs, which describe actions and happenings in the outside, material world. ${ }^{81}$ These can be subdivided into material processes and behavioural processes and in the case of elle, we find that behavioural processes account for $84 \%$ and material processes for $16 \%$ of the 'doing' verbs associated with the female pronoun. ${ }^{82}$ About $7 \%$ of the surrounding verbs can be categorised as 'projecting' verbs that describe the inner world of cognition, perception, emotions and desire (mental processes), as well as thought and speech (verbal processes). It is striking that none of the 'projecting' verbs describe verbal processes, and the mental processes represent wishful thoughts, which tells of women in a more passive role of thinking rather than verbal expression. ${ }^{83}$ 'Being' verbs that encode existential processes, on the one hand, and relational ones, on the other, account for just over $21 \%$ of the verbs relating to elle. ${ }^{84}$ Of these, $73 \%$ are concerned with a woman's relationship to others, rather than to existential processes.

81 For a detailed description of the clause as processes and the different categories of processes, see David Butt, Rhondda Fahey, Susan Feez, Sue Spinks and Colin Yallop, eds. Using Functional Grammar. An Explorer's Guide (Sydney: Macquarie University 2000), 50-52.

82 Examples of 'doing' verbs describing material processes: ocirre (kill), damagier (damage), fere (do); describing behavioural processes: choisir (choose), trover (find), marier (marry).

83 Examples of 'projecting' verbs describing mental processes: heent (hate), velt (want), voudra (wish)

84 Examples of 'being' verbs describing existential processes: est seule/vueve (is alone/a widow); describing relational processes: avra son doere/mari (has her dower/husband). 
Also striking is the fact that just under $30 \%$ of the verbal groups relating to the personal pronoun elle actually depict that woman (usually in the singular form) in a passive role - things are being done to her or on her behalf by others, e.g. elle a esté prise a force (she was taken by force), elle doit estre envoiee a l'evesque (she must be sent to the bishop).

\begin{tabular}{|c|c|c|c|}
\hline $\begin{array}{l}\text { Category of pro- } \\
\text { cesses }\end{array}$ & $\begin{array}{c}\text { Total } \\
\text { (208 verbs) }\end{array}$ & Subtotal & Subcategory of processes \\
\hline \multirow[t]{2}{*}{ ‘doing’ verbs } & 77 & 12 & material processes \\
\hline & $37 \%$ & 65 & behavioural processes \\
\hline \multirow[t]{2}{*}{ 'projecting' verbs } & 15 & 15 & mental processes \\
\hline & $7 \%$ & 0 & verbal processes \\
\hline \multirow[t]{2}{*}{ ‘being’ verbs } & 44 & 12 & existential processes \\
\hline & $21 \%$ & 32 & relational processes \\
\hline 'passive' voice & $\begin{array}{r}60 \\
29 \% \\
\end{array}$ & & \\
\hline 'modal' verbs & $\begin{array}{r}14 \\
7 \% \\
\end{array}$ & $\begin{array}{l}\text { 'can': } 10 \mathrm{x} \\
\text { 'must': } 4 \mathrm{x}\end{array}$ & \\
\hline
\end{tabular}

Table 2: processes directly associated with elle in Le très ancien coutumier de Normandie

From this rapid overview of the processes associated with the female personal pronoun elle, we can observe that in $37 \%$ we are dealing with 'doing' verbs. This is, in part, to be expected as the Coutumier is a legal text that lays down pragmatic rules on how to act. It concerns itself less with emotions, other mental or relational processes, yet these account for $28 \%$ of the verbs. Passive-voice verbs represent almost $30 \%$ of the processes. In other words, the language surrounding processes directly connected to elle tends to relate to existence, identification, relationships and matters of mental/emotional nature. All in all, these reflect a more passive than active aspect of the experiential world.

As far as the circumstances described in the KWIC lines are concerned, we can observe that from the contextual information, the 80 
KWIC lines deal in roughly equal proportions with questions of land/ property, marriage/family, inheritance, dower, criminal matters and rape. Classifying context into categories is always somewhat problematic, as inevitably there is some overlap. Discussions of, for example, dower involve questions of marriage, inheritance and land/property. The classification were made according to what issues had most weight in each KWIC line. If we group inheritance, marriage/family and dower together we come to $45 \%$ of the KWIC that deal with these issues. Crime and violence come together to $25 \%$, of which just over half is concerned with rape.

\begin{tabular}{|l|l|r|r|r|r|}
\hline Context & $\begin{array}{l}\text { Descrip- } \\
\text { tion }\end{array}$ & $\begin{array}{l}\text { Number } \\
\text { of KWIC } \\
\text { lines }\end{array}$ & $\begin{array}{c}\text { \% of 80 } \\
\text { KWIC } \\
\text { lines }\end{array}$ & & \multicolumn{1}{|c|}{$\begin{array}{c}\text { Number \& \% } \\
\text { of 80 KWIC } \\
\text { lines }\end{array}$} \\
\hline L/P & $\begin{array}{l}\text { land/ } \\
\text { property }\end{array}$ & 14 & $18 \%$ & & \\
\hline F/I & $\begin{array}{l}\text { inheri- } \\
\text { tance, } \\
\text { family, } \\
\text { marriage, } \\
\text { dower }\end{array}$ & 36 & $45 \%$ & inheritance & 12 or $15 \%$ \\
\cline { 5 - 6 } & & & & marriage/family & 4 or $6 \%$ \\
\hline Cr. & $\begin{array}{l}\text { crime, } \\
\text { violence, } \\
\text { rape }\end{array}$ & 20 & $25 \%$ & dower & 10 or $13 \%$ \\
\cline { 4 - 5 } & & & crime & 9 or $11 \%$ \\
\hline
\end{tabular}

Table 3: contexts in which elle occurs in Le très ancien coutumier de Normandie

\section{2 'Fame/fames'}

The descriptio fame in its singular and plural form occurred 63 times ${ }^{85}$ in Le très ancien coutumier de Normandie, which represents 35 instances per 10,000 words. The first five nouns with which fame* collocates are: dower, force, woman, inheritance, and husband, ${ }^{86}$ and the first three verbs: to be, must and have. ${ }^{87}$ The results of the cluster tool show these words to be similarly prominent in clustering around the search term.

\footnotetext{
85 fame: 58 hits; fames: 5 hits.

86 doere, force, fame, eritage, mari.

87 est, doit, avoir.
} 
The advanced proximity search shows different emphasis from the one around the search term elle. Doere is the term that stands out with the highest proximity hits, also in relation to its occurrence in the corpus $(\mathrm{P} / \mathrm{N})$, as well as a percentage of the occurrence of fame $\left(\mathrm{P} / \mathrm{N}_{0}\right)$. These figures are higher than for doere in proximity of elle. Another term that ranks high in this advanced search, while yielding very few hits in relation to elle, is mort (in both its adjective and noun form). The results are about half of that for doere but are still ahead of other terms. The figures for heritage are very similar. Furthermore, we can observe a number of other terms with low relative frequencies in relation to the whole corpus, but with a high rate of occurrence in the vicinity of fame. For example, all 7 occurrences of vueve can be found within 10 words of the main search term. Other words with a relatively high $\mathrm{P} / \mathrm{N}$ score are marriage, tierz, mère and mechine.

\begin{tabular}{|l|r|r|r|r|r|}
\hline $\begin{array}{c}\text { search } \\
\text { term }\end{array}$ & \multicolumn{1}{|c|}{$\begin{array}{c}\text { hits } \\
(=\mathrm{N})\end{array}$} & $\begin{array}{c}\text { rel. freq. } \\
(10,000 \\
\text { words })\end{array}$ & $\begin{array}{c}\text { proximity } \\
\text { occurrences } \\
(=\mathrm{P})\end{array}$ & $\begin{array}{c}\text { relative } \\
\text { proximity } \\
(=\mathrm{P} / \mathrm{N})\end{array}$ & $\begin{array}{c}\text { prox. to } \\
\text { (fame } \\
\left(=\mathrm{P} / \mathrm{N}_{0}\right)\end{array}$ \\
\hline fame & $63\left(=\mathrm{N}_{0}\right)$ & $\mathbf{3 5}$ & $\mathbf{N} / \mathbf{A}$ & $\mathbf{N} / \mathrm{A}$ & $\mathbf{N} / \mathrm{A}$ \\
\hline terre & 129 & 71 & 4 & $3 \%$ & $6 \%$ \\
\hline homme & 107 & 59 & 4 & $4 \%$ & $6 \%$ \\
\hline héritage & 74 & 41 & 12 & $16 \%$ & $19 \%$ \\
\hline mort & 40 & 22 & 10 & $25 \%$ & $16 \%$ \\
\hline doere & 37 & 20 & 17 & $46 \%$ & $27 \%$ \\
\hline tierz & 27 & 15 & 7 & $26 \%$ & $11 \%$ \\
\hline mariage & 26 & 14 & 7 & $27 \%$ & $11 \%$ \\
\hline fille & 14 & 8 & 1 & $7 \%$ & $2 \%$ \\
\hline mère & 12 & 7 & 3 & $25 \%$ & $5 \%$ \\
\hline vueve & 7 & 4 & 7 & $100 \%$ & $11 \%$ \\
\hline mechine & 5 & 3 & 3 & $60 \%$ & $5 \%$ \\
\hline
\end{tabular}

Table 4: search terms/proximity to fame in Le très ancien coutumier de Normandie 
As far as processes are concerned the data shows similar tendencies to those in the searches for elle above. The 'doing' verbs are most frequent (32\%) and the subdivision between material and behavioural processes is more balanced (14/30 and 16/30). These are closely followed by both the 'being' verbs, favouring relational processes, and the passive-voice verbs. There are too few data points for the 'projecting' verbs data to allow its details to tell a story. However, the general picture is similar to that of elle: women are represented in more passive and relational processes rather than active material ones. These findings are particularly interesting to consider in the light of the data obtained for the equivalent terms relating to the male presence in the text.

\begin{tabular}{|l|r|r|l|}
\hline \multicolumn{1}{|c|}{$\begin{array}{c}\text { Category of } \\
\text { processes }\end{array}$} & $\begin{array}{c}\text { Total } \\
\text { (95 verbs) }\end{array}$ & Subtotal & Subcategory of processes \\
\hline 'doing' verbs & 30 & 14 & material processes \\
\cline { 3 - 5 } & $32 \%$ & 16 & behavioural processes \\
\hline 'projecting' & 2 & 1 & mental processes \\
\cline { 2 - 4 } & $2 \%$ & 1 & verbal processes \\
\hline 'being' verbs & 27 & 7 & existential processes \\
\cline { 3 - 4 } & $28 \%$ & 20 & relational processes \\
\hline 'passive' voice & 27 & & \\
\hline 'modal' verbs & $28 \%$ & & \\
\hline
\end{tabular}

Table 5: processes directly associated with fame in Le très ancien coutumier de Normandie

Observing the circumstances described in the 63 KWIC lines in which the term fame occurs, we find that dower, inheritance, family and marriage are the most likely contexts, as documented in Table 6, which reflects the results for the search term elle. In the context of fame, dower is discussed considerably more often than inheritance or marriage/family. References to legal matters or court proceedings, to homage and duties 
or to church matters, appear to be absent, through these are important in textual contexts relating to male descriptios such as il and home (see below).

\begin{tabular}{|l|l|r|r|r|r|}
\hline $\begin{array}{c}\text { Con- } \\
\text { text }\end{array}$ & Description & $\begin{array}{l}\text { Number } \\
\text { of KWIC } \\
\text { lines }\end{array}$ & $\begin{array}{c}\text { \% of 63 } \\
\text { KWIC } \\
\text { lines }\end{array}$ & & $\begin{array}{c}\text { Number \& \% } \\
\text { of 63 KWIC } \\
\text { lines }\end{array}$ \\
\hline L/P & $\begin{array}{l}\text { land/ } \\
\text { property }\end{array}$ & 11 & $17 \%$ & & \\
\hline F/I & $\begin{array}{l}\text { inheritance, } \\
\text { family, } \\
\text { marriage, } \\
\text { dower }\end{array}$ & 33 & $52 \%$ & inheritance & 11 or $17 \%$ \\
\cline { 5 - 6 } & & & marriage/family & 4 or $6 \%$ \\
\hline Cr. & $\begin{array}{l}\text { crime, } \\
\text { violence, } \\
\text { rape }\end{array}$ & 19 & $30 \%$ & dower & 18 or $29 \%$ \\
\cline { 4 - 6 } & & & crime & 10 or $16 \%$ \\
\hline
\end{tabular}

Table 6: contexts in which fame occurs in Le très ancien coutumier de Normandie

\section{3 ' $I L$ '}

The masculine personal pronoun il occurs 601 times $^{88}$ in Le très ancien coutumier de Normandie, which represents 331 times per 10,000 words. The first few nouns with which il collocates are: land, duke, woman, justice, possession, ${ }^{89}$ and the first three verbs: to be, must and do. ${ }^{90}$ The results of the cluster tool shows these words to be similarly prominent.

The advanced proximity search shows considerably higher figures for the same terms in proximity of $i l$ than for the equivalent female personal pronoun. This is particularly the case for the $\mathrm{P} / \mathrm{N}$ values, while the $\mathrm{P} / \mathrm{N}_{0}$ values are low and always lower than the former, which can in part be explained by the fact that $i l$ has a much higher frequency $\left(\mathrm{N}_{0}\right)$. Men are described in a variety of ways and roles and the descriptios stand

\footnotetext{
88 As the search for $i l$ yielded a relatively large amount of data, other spelling variations such as, for example, ill were not taken into account.

89 Terre, duc, fame, justice, possession. The size of the search span is ten words to the left and to the right of the search term.

90 est, doit, fet
} 
out as frequent in the proximity of il such as, for example, the terms duc, seigneur and homme, which can be found in 75\%, 68\% and 53\% respectively of their occurrences in the vicinity of il. Although that is to be expected, it was not reflected in the descriptios for women in the proximity of elle, where only fame scored relatively high with $30 \%$, while suer, fille, mère, vueve, mechine are all $10 \%$ or under. The other terms that stand out relate to land, property and inheritance. The term tenement figures with $53 \%$ and terre with $48 \%$ of their occurrence can they be found in the vicinity of $i l$. Questions of inheritance in the il-KWIC lines are raised with the use of heritage (P/N: 55\%), tierz (P/N: 52\%) and doere $(\mathrm{P} / \mathrm{N}: 27 \%)$, all percentages refer to the relative proximity calculated of the overall occurrence in the whole corpus of the terms in question.

\begin{tabular}{|l|r|r|r|r|r|}
\hline $\begin{array}{c}\text { search } \\
\text { term }\end{array}$ & \multicolumn{1}{|c|}{$\begin{array}{c}\text { hits } \\
(=\mathrm{N})\end{array}$} & $\begin{array}{c}\text { rel. freq. } \\
(10,000 \\
\text { words })\end{array}$ & $\begin{array}{c}\text { proxim- } \\
\text { ity occur- } \\
\text { rences } \\
(=\mathrm{P})\end{array}$ & $\begin{array}{c}\text { relative } \\
\text { proximity } \\
(=\mathrm{P} / \mathrm{N})\end{array}$ & $\begin{array}{c}\text { prox. to 'il' } \\
\left(=\mathrm{P} / \mathrm{N}_{0}\right)\end{array}$ \\
\hline il & $\mathbf{6 0 1}\left(=\mathrm{N}_{0}\right)$ & 331 & $\mathbf{N} / \mathbf{A}$ & $\mathbf{N} / \mathbf{A}$ & N/A \\
\hline terre & 129 & 71 & 62 & $48 \%$ & $10 \%$ \\
\hline homme & 107 & 9 & 57 & $53 \%$ & $10 \%$ \\
\hline heritage & 74 & 41 & 41 & $55 \%$ & $7 \%$ \\
\hline fame & 63 & 35 & 26 & $41 \%$ & $4 \%$ \\
\hline eglise & 62 & 34 & 24 & $39 \%$ & $4 \%$ \\
\hline duc & 60 & 33 & 45 & $75 \%$ & $8 \%$ \\
\hline roi & 56 & 31 & 22 & $39 \%$ & $4 \%$ \\
\hline doere & 37 & 20 & 10 & $27 \%$ & $2 \%$ \\
\hline mort & 40 & 22 & 30 & $75 \%$ & $5 \%$ \\
\hline seigneur & 40 & 22 & 27 & $68 \%$ & $5 \%$ \\
\hline tenement & 40 & 22 & 21 & $53 \%$ & $4 \%$ \\
\hline chevalier & 38 & 21 & 18 & $47 \%$ & $3 \%$ \\
\hline evesque & 35 & 19 & 19 & $54 \%$ & $3 \%$ \\
\hline pere & 32 & 18 & 20 & $63 \%$ & $3 \%$ \\
\hline
\end{tabular}




\begin{tabular}{|l|r|r|r|r|r|}
\hline suer & 29 & 16 & 14 & $48 \%$ & $2 \%$ \\
\hline frere & 28 & 15 & 8 & $29 \%$ & $1 \%$ \\
\hline tierz & 27 & 15 & 14 & $52 \%$ & $2 \%$ \\
\hline mariage & 26 & 14 & 6 & $23 \%$ & $1 \%$ \\
\hline filz & 25 & 13 & 7 & $28 \%$ & $1 \%$ \\
\hline sires & 21 & 12 & 12 & $57 \%$ & $2 \%$ \\
\hline fille & 14 & 8 & 8 & $57 \%$ & $1 \%$ \\
\hline
\end{tabular}

Table 7: search terms/proximity to il in Le très ancien coutumier de Normandie

When studying in greater detail the KWIC lines that were the result of the concordance search for $i l$, it was necessary to create roughly equivalent material to the same study relating to the elle KWIC lines. As the concordance search for il yielded 601 KWIC lines, which is over seven times more than the female equivalent, a random selection of every seventh line give some 86 KWIC lines to be considered in greater detail. A total of 217 verbal groups can be found in these lines, of which well over half are 'doing' verbs, while it was $37 \%$ for the elle study. 'Projecting' verbs account for $7 \%$, which is the same in the case of the female pronoun, which however includes both verbal and mental processes. 'Being' verbs can be found in $16 \%$ of the verbal groups of which the majority are relational processes. Verbs that show the man in a passive position in the process only account up for $14 \%$ as opposed to $29 \%$ in the elle study.

\begin{tabular}{|l|r|r|l|}
\hline \multicolumn{1}{|c|}{$\begin{array}{c}\text { Category of } \\
\text { processes }\end{array}$} & $\begin{array}{c}\text { Total } \\
\text { (217 verbs) }\end{array}$ & Subtotal & Subcategory of processes \\
\hline 'doing' verbs & 121 & 26 & material processes \\
\cline { 3 - 4 } & $56 \%$ & 95 & behavioural processes \\
\hline 'projecting' verbs & 14 & 9 & mental processes \\
\cline { 3 - 4 } & $7 \%$ & 5 & verbal processes \\
\hline
\end{tabular}




\begin{tabular}{|l|r|r|l|}
\hline 'being' verbs & 35 & 7 & existential processes \\
\cline { 2 - 3 } & $16 \%$ & 28 & relational processes \\
\hline 'passive' voice & 30 & \multicolumn{2}{|l|}{} \\
\hline 'modal' verbs & $14 \%$ & & \\
& 17 & \multicolumn{2}{|l}{} \\
\hline
\end{tabular}

Table 8: processes directly associated with il in Le très ancien coutumier de Normandie

As far as the context is concerned in terms of participants and circumstances, we find a very different situation to that surrounding the female pronoun elle. Just under half of the KWIC lines deal with legal and court proceedings, a category that is absent from the elle KWIC lines. Of these, a few deal with criminal matters and one with rape, while all the others deal with issues such as court proceedings, pleadings and appearances, the purging of sentences etc. The second largest category relate to land and property and can be found in $22 \%$ of the KWIC lines. Issues of inheritance, family and marriage can only be found in $10 \%$ of the KWIC lines. A further $9 \%$ of the KWIC lines are concerned with issues of political power and procedural matters of the duke, barons, knights and bishops etc.

\begin{tabular}{|l|l|r|r|r|r|}
\hline Context & Description & $\begin{array}{r}\text { Number } \\
\text { of KWIC } \\
\text { lines }\end{array}$ & $\begin{array}{c}\text { \% of 86 } \\
\text { selected } \\
\text { KWIC } \\
\text { lines }\end{array}$ & $\begin{array}{c}\text { Number \& \% } \\
\text { of 86 KWIC } \\
\text { lines }\end{array}$ \\
\hline $\mathrm{P}$ & $\begin{array}{l}\text { power: } \\
\text { political, } \\
\text { homage \& } \\
\text { duties, church }\end{array}$ & 8 & $9 \%$ & & \\
\hline L/P & $\begin{array}{l}\text { land/ } \\
\text { property }\end{array}$ & 19 & $22 \%$ & & \\
\hline F/I & $\begin{array}{l}\text { inheritance, } \\
\text { family, } \\
\text { marriage }\end{array}$ & 9 & $10 \%$ & & \\
\hline
\end{tabular}




\begin{tabular}{|l|l|r|r|r|r|}
\hline Cr./L & $\begin{array}{l}\text { court } \\
\text { proceedings, } \\
\text { legal, law, } \\
\text { crime, } \\
\text { violence }\end{array}$ & 38 & $44 \%$ & $\begin{array}{r}\text { legal pro- } \\
\text { ceedings }\end{array}$ & 31 or $36 \%$ \\
\cline { 4 - 5 } & & & crime & 6 or $7 \%$ \\
\hline $\begin{array}{l}\text { not } \\
\text { relevant }\end{array}$ & $\begin{array}{l}\text { il does not } \\
\text { refer to homme }\end{array}$ & 12 & $14 \%$ & rape & 1 or $1 \%$ \\
\hline
\end{tabular}

Table 9: contexts in which il occurs in Le très ancien coutumier de Normandie

\section{4 'Home'}

The descriptio for 'man' has several spellings in Le très ancien coutumier de Normandie: home and the plural form homes, hom and the plural form homs, homme and its plural form hommes, and finally omme. All spellings variants considered the term occurs 107 times in the Coutumier, which represents a relative frequency of 59 per 10,000 words. The absolute frequency for every variation is as follows:

\begin{tabular}{|l|r|}
\hline Spelling variation & Absolute frequency \\
\hline home & 34 \\
\hline homes & 36 \\
\hline hom & 9 \\
\hline homs & 16 \\
\hline homme & 2 \\
\hline hommes & 8 \\
\hline omme & 2 \\
\hline
\end{tabular}

Table 10: spelling variations for home in Le très ancien coutumier de Normandie

The variety in spelling has meant that the various searches were more complex as every variation had to be taken into account and the results needed to be compounded. The advanced proximity searches show similar trends to those around the male pronoun il to the extent that the highest relative proximity $(\mathrm{P} / \mathrm{N})$ is for terre, mort and tenement. The exact 
value of these figures is less appropriate to compare as the relative frequency for $i l$ is so much higher. The terms tierz, filz and fille show similar figures but their relative frequency is also very fairly low.

\begin{tabular}{|l|r|r|r|r|r|}
\hline $\begin{array}{c}\text { search } \\
\text { term }\end{array}$ & \multicolumn{1}{|c|}{$\begin{array}{c}\text { hits } \\
(=\mathrm{N})\end{array}$} & $\begin{array}{c}\text { rel. freq. } \\
(10,000 \\
\text { words })\end{array}$ & $\begin{array}{c}\text { proximity } \\
\text { occurrences } \\
(=\mathrm{P})\end{array}$ & $\begin{array}{c}\text { relative } \\
\text { proximity } \\
(=\mathrm{P} / \mathrm{N})\end{array}$ & $\begin{array}{c}\text { prox. to } \\
\text { 'home' } \\
\left(=\mathrm{P} / \mathrm{N}_{0}\right)\end{array}$ \\
\hline home & $\mathbf{1 0 7}\left(=\mathrm{N}_{0}\right)$ & $\mathbf{5 9}$ & $\mathbf{N} / \mathbf{A}$ & $\mathbf{N} / \mathbf{A}$ & $\mathbf{N} / \mathbf{A}$ \\
\hline terre & 129 & 71 & 16 & $12 \%$ & $15 \%$ \\
\hline heritage & 74 & 41 & 2 & $3 \%$ & $2 \%$ \\
\hline eglise & 62 & 34 & 4 & $6 \%$ & $4 \%$ \\
\hline doere & 37 & 20 & 1 & $3 \%$ & $1 \%$ \\
\hline mort & 40 & 22 & 5 & $13 \%$ & $5 \%$ \\
\hline tenement & 40 & 22 & 4 & $10 \%$ & $4 \%$ \\
\hline pere & 32 & 18 & 3 & $9 \%$ & $3 \%$ \\
\hline tierz & 27 & 15 & 3 & $11 \%$ & $3 \%$ \\
\hline mariage & 26 & 14 & 1 & $4 \%$ & $1 \%$ \\
\hline filz & 25 & 13 & 3 & $12 \%$ & $3 \%$ \\
\hline fille & 14 & 8 & 2 & $14 \%$ & $2 \%$ \\
\hline
\end{tabular}

Table 11: search terms/proximity to home in Le très ancien coutumier de Normandie

When studying closely the KWIC lines, we can observe that home is not used in the generic way as it would be today. In the Coutumier it tends to refer to men of inferior status, vassals and subjects, and the contexts are instructions and descriptions of mandatory rules and processes. This is reflected in the fact that a relatively high proportion of processes in which home is a passive participant. The figure of $29 \%$ is the same as that for elle and for fame (28\%), while for the male personal pronoun il it is only $14 \%$. As for the other processes, the data for home is closer to that for $i l$ than to the female equivalent of elle and fame with more emphasis on doing rather than being. 


\begin{tabular}{|c|c|c|c|}
\hline $\begin{array}{l}\text { Category of } \\
\text { processes }\end{array}$ & $\begin{array}{c}\text { Total } \\
\text { (161 verbs) }\end{array}$ & Subtotal & Subcategory of processes \\
\hline \multirow[t]{2}{*}{ ‘doing’ verbs } & 71 & 21 & material processes \\
\hline & $44 \%$ & 50 & behavioural processes \\
\hline \multirow[t]{2}{*}{ 'projecting' verbs } & 8 & 7 & mental processes \\
\hline & $5 \%$ & 1 & verbal processes \\
\hline \multirow[t]{2}{*}{ ‘being’ verbs } & 25 & 3 & existential processes \\
\hline & $16 \%$ & 22 & relational processes \\
\hline 'passive' voice & $\begin{array}{r}46 \\
29 \% \\
\end{array}$ & & \\
\hline 'modal' verbs & $\begin{array}{r}11 \\
7 \%\end{array}$ & & \\
\hline
\end{tabular}

Table 12: processes directly associated with home in Le très ancien coutumier de Normandie

When considering the circumstances described in the 107 KWIC lines (Table 13), we can observe that legal/court proceedings and land/property are the most likely contexts in which the term home can be found. Comparing the percentages with those obtained for the male pronoun $i l$, we can observe similar figures, except for the category of political power, homage and duties and church matters which constituted twice as much context in the case of home. Issues around crime and violence are also more prominent but rape only represents 1\% of the $107 \mathrm{KWIC}$ lines.

The comparison with the contexts in which we can find the female equivalent fame is more telling. Matters relating to legal and court proceedings can be found in $32 \%$ of the 107 KWIC lines. This category is absent in the equivalent female terms, as is the one relating to political power, homage and duties, and church matters. Striking is the low percentage for inheritance, family matters, marriage and dower: $7 \%$ as opposed to $52 \%$ in the context of fame. Dower is only mentioned once, while it constituted the context of $29 \%$ of the 63 KWIC lines for fame. Rape is another issue that hardly constitutes the context for home. The comparison with the context around the male personal pronoun $i l$, shows 
very similar percentages, except for the category of political power, homage and duties, and church matters, where the figure for home has doubled in comparison with the search around $i l$.

\begin{tabular}{|c|c|c|c|c|c|}
\hline Context & Description & $\begin{array}{c}\text { Number } \\
\text { of KWIC } \\
\text { lines }\end{array}$ & $\begin{array}{c}\% \text { of } 107 \\
\text { KWIC } \\
\text { lines }\end{array}$ & & $\begin{array}{c}\text { Number \& } \\
\% \text { of } 107 \\
\text { KWIC lines }\end{array}$ \\
\hline $\mathrm{P}$ & $\begin{array}{l}\text { power: } \\
\text { political, } \\
\text { homage \& } \\
\text { duties, church }\end{array}$ & 19 & $18 \%$ & & \\
\hline $\mathrm{L} / \mathrm{P}$ & $\begin{array}{l}\text { land/ } \\
\text { property }\end{array}$ & 29 & $27 \%$ & & \\
\hline $\mathrm{F} / \mathrm{I}$ & $\begin{array}{l}\text { inheritance, } \\
\text { family, } \\
\text { marriage }\end{array}$ & $\begin{array}{r}7 \\
\text { (dower 1x) }\end{array}$ & $7 \%$ & & \\
\hline \multirow[t]{3}{*}{ Cr./L } & \multirow{3}{*}{$\begin{array}{l}\text { court } \\
\text { proceedings, } \\
\text { legal, law, } \\
\text { crime, } \\
\text { violence }\end{array}$} & \multirow[t]{3}{*}{52} & \multirow[t]{3}{*}{$49 \%$} & $\begin{array}{l}\text { court/legal } \\
\text { proceedings }\end{array}$ & 34 or $32 \%$ \\
\hline & & & & $\begin{array}{l}\text { crime, } \\
\text { violence }\end{array}$ & 17 or $16 \%$ \\
\hline & & & & rape & 1 or $1 \%$ \\
\hline
\end{tabular}

Table 13: contexts in which home occurs in Le très ancien coutumier de Normandie

\section{5 'Doere'}

The linguistic study of both elle and fame highlighted the importance of dower. While the term has a fairly low relative frequency (20 per 10,000 words), in $46 \%$ and $30 \%$ of its occurrences it can it be found in the vicinity of respectively fame and elle. This is to be expected to the extent that dower is a subject particularly associated with (married) women. Yet when we examine the processes directly associated with doere in the KWIC lines, we can observe that in $44 \%$ of the lines women are passive participants. In other words, despite dower being one of the few occasion when women are invested with what could be construed as a 'right', she is in a passive position in relation to the processes in about half of the refences in the Coutumier. She is depicted with a more active voice 
in just under a third of the cases where women actively ask/claim her dower rights, e.g. se fame demande doere or sa fame atandra son doere. The remaining cases describe women as actually possessing the dower (rights), e.g. elle avra son doere en la terre.

The advanced proximity search of ten words to the left and right of doere shows relative high frequencies for fame and mort, also for tierz, marriage, mère, vueve though these four show a low relative frequency in the corpus.

\section{Conclusions}

Women in the High Middle Ages are generally thought of as having very limited agency and that on marriage the little legal capacity they may have enjoyed as unmarried women or as widows evaporated as they came under the control of their husbands. This paper shows that such perceptions need to be refined.

The lack of women's legal capacity in customary law is a theme with variations according to regions and whether we are basing ourselves on written customary law texts only (law-on-paper) or whether we also consider other sources such as court records, private wills etc. (law-inaction), which are more driven by pragmatics. In this paper, we have concentrated on the written thirteenth century customary law of Normandy, in particular the contemporaneous French translation of Le très ancien coutumier de Normandie.

A detailed linguistic analysis of the Norman coutumier, as produced in the manuscript of the Bibliothèque Sainte-Geneviève in Paris, has shown an overwhelming discrepancy between the textual presence of women and that of men. As we can observe from the charts below, there is a greater variety of categories of descriptios for men than for women. ${ }^{91}$

91 Men: il; homes/home/homs/hom/hommes/homme/omme; segneur/segneurs/seigneur; chevalier/chevalier; sire; freres/frer/frères/; peres/pere/père; filz/fill/fil; mari/mariz; senechau/senechal; sergent; baron/barons; arcevesque/arcevesques; ainznez/ainzné; borjoir; prestress; cousins/cosins/cousin; neveu.

Women: elle/elles; fame/fames; suer/suers; fille/filles; mere/mère; mechine/meschine; vueve/vueves; ainznee; pucelle; cousine. 
Men not only have a considerably higher textual presence in the Coutumier, they are also represented in a greater variety of roles. The references to women are predominantly in relation to their family set-up or marital status but never to anything that may reveal socio-political or religious power of action and influence or professional activities. In other words, the narrative told of men in the Coutumier is not only more substantial but also considerably more varied and thus contextually richer.

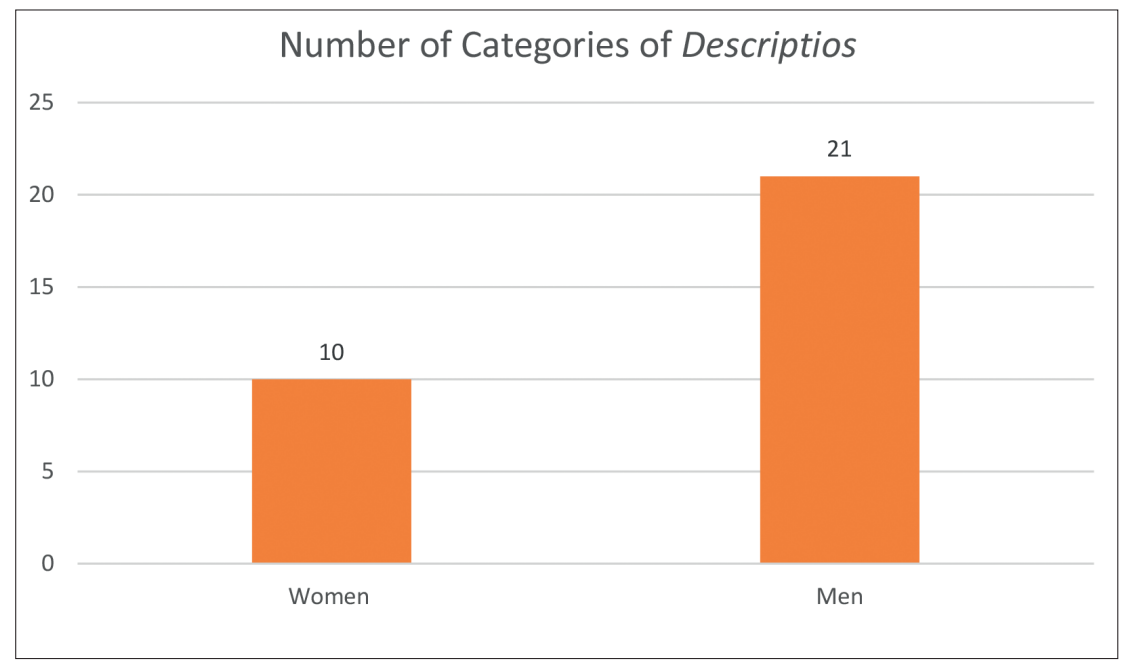

Chart 1: categories of descriptios for women and men in Le très ancien coutumier de Normandie 


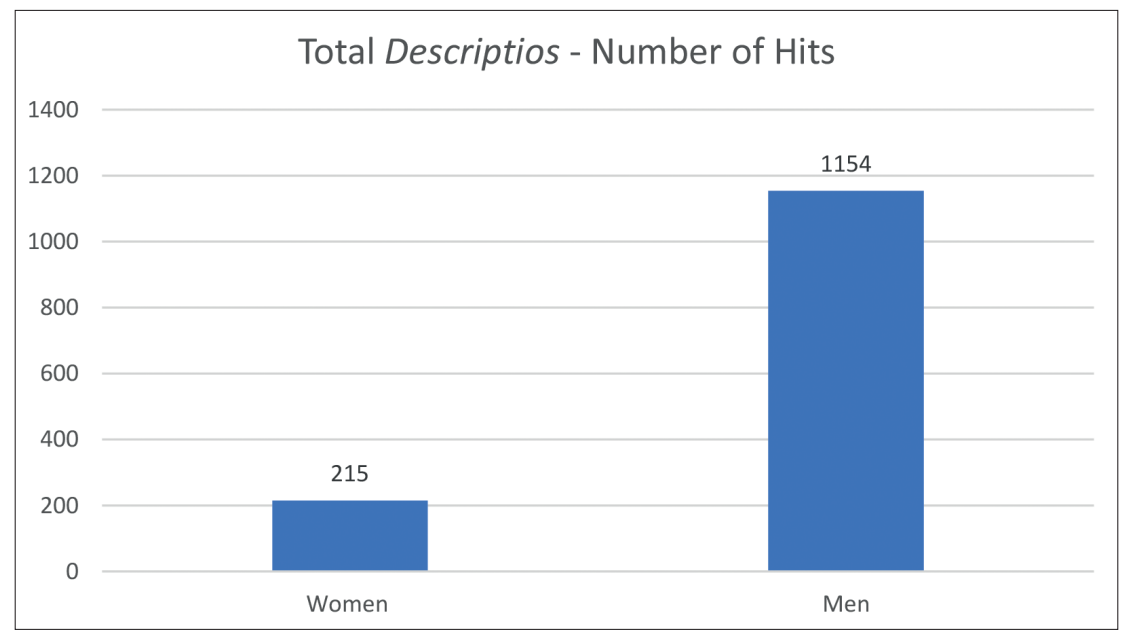

Chart 2: number of occurrences for all descriptios for women and men in Le très ancien coutumier de Normandie

This is also borne out by the figures in Chart 3, which details some of the gender descriptios. ${ }^{92}$ We can observe that the term fame not only occurs considerably less than its male equivalent but also approximately as often as $d u c$ and only slightly more than roi. In other words, a generic term that describes approximately half the population occurs roughly as often as the term 'duke', which is used to describe only one person/office in Normandy. The family-related descriptios are also dominant for men: fils, pere, frere, mari are all ahead of their female equivalent, except for suer, which occurs almost as often as frere.

92 All spelling variations were included. 


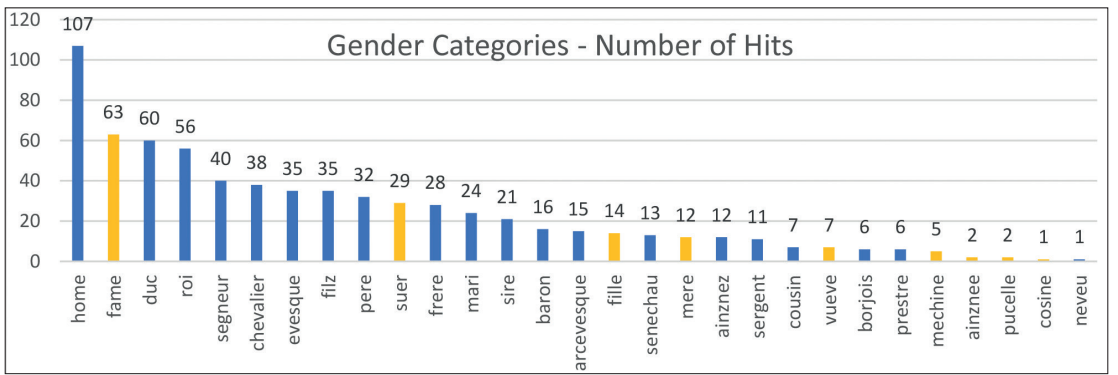

Chart 3: number of occurrences for all gender categories in Le très ancien coutumier de Normandie

Despite the considerably higher textual presence of references to men, we can observe from the proximity searches that certain terms referring to matters of a legal nature can be found far more often in contexts relating to women than men. Charts 4 and 5 set out the figures of the proximity searches for terms that relate to legal concepts or status. While we may expect to find references to women mentioned more often in discussion relating to dower (doere) or the 'third' (tierz) of her husband's estate that she can expect will be settled on her, it is surprising that the terms heritage and marriage are also predominately associated with women. One would expect men to be involved as much as women in matters of inheritance and marriage, but the proximity figures do not appear to bear that out. It would, therefore, be reasonable to conclude that discussions of marriage, inheritance, dower and the third settled on married women mainly relate to women. 


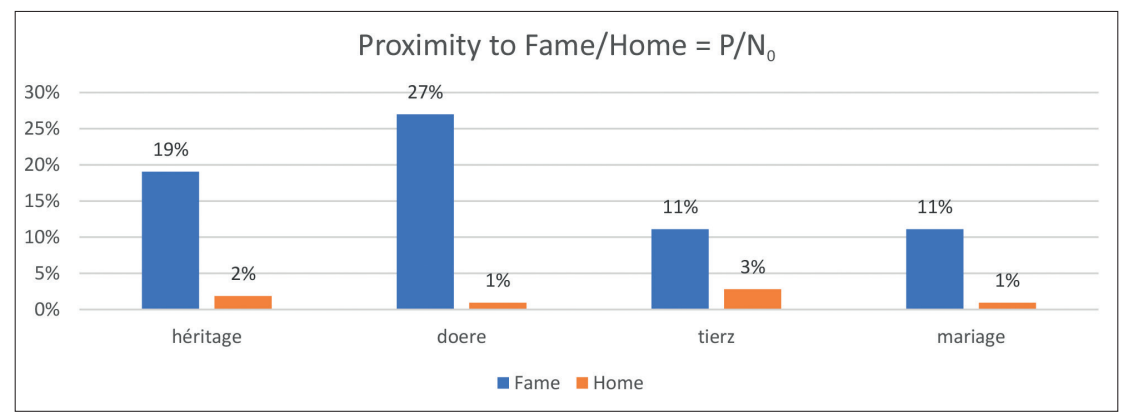

Chart 4: Proximity of secondary terms (relating to legal concepts) to fame/ home

$(\mathrm{P}=$ absolute proximity frequency of secondary search terms to primary search term;

$\mathrm{N}_{0}=$ absolute frequency of primary search term)

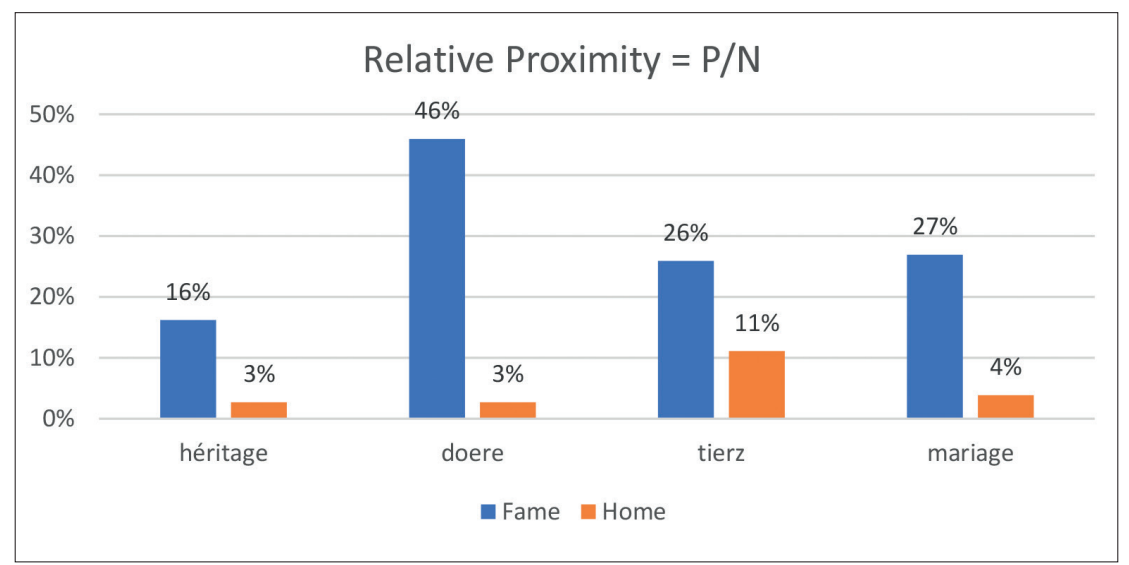

Chart 5: Relative proximity of secondary terms to fame/home

$(\mathrm{P}=$ absolute proximity frequency of secondary search term to primary search term;

$\mathrm{N}=$ absolute frequency of secondary search term)

A closer look at the context in which the terms fame and home occur (Chart 6) confirms the findings of the proximity study. In over half of the KWIC lines for women, the context relates to matters of inheritance, family, dower, or marriage. However, issues of land and property, although at the heart of discussion about inheritance and dower are more associ- 
ated with men. So are court and legal proceedings, crimes and violence, as well as matters of political power, feudal homage and duties, the last category is entirely absent in the KWIC lines for fame.

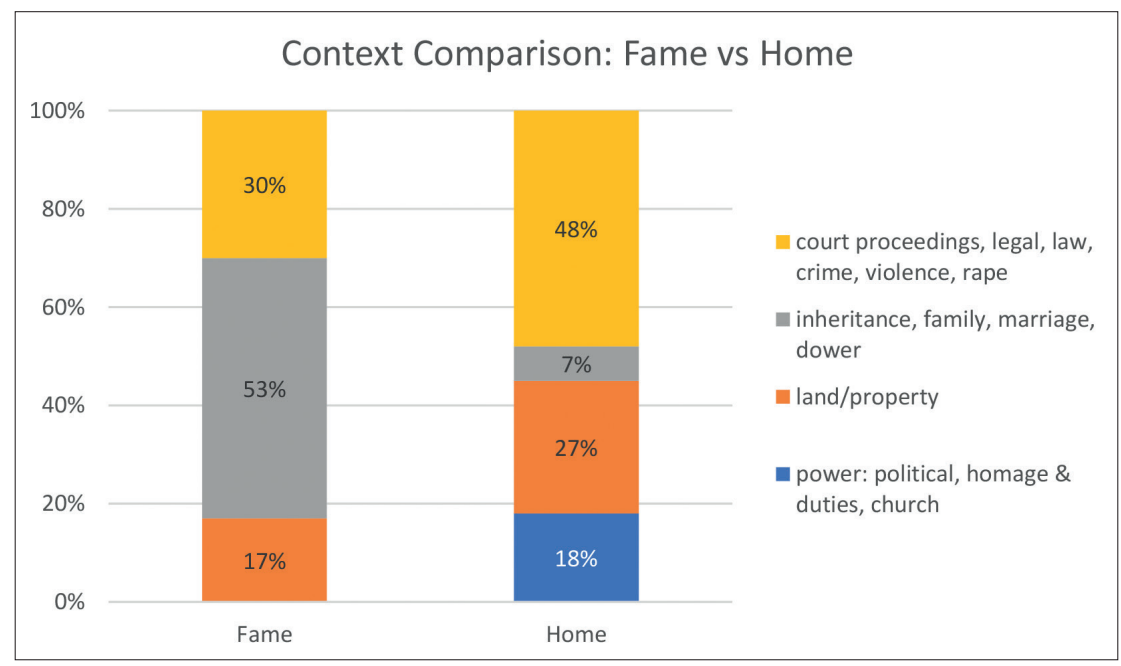

Chart 6: context comparison of KWIC lines for fame and home

The female voice is rather feeble in Le très ancien coutumier de Normandie, which is particularly striking in the comparative data sets that highlight the extent of the discrepancies when set side by side with the equivalent male terms. But in the context of some matters, references to women are considerably higher than to men. Yet, as we saw from the study of the processes that dominate the relevant KWIC lines, the verbal groups tend not to reflect active participation. A priori, this linguistic study of the Coutumier confirms the assumption that women in thirteenth century Normandy had relatively low legal capacity and found themselves in asymmetrical dependencies on men, especially on husbands. Some provisions were made for them, in particular in relation to dower and rape, and they were provided with (legal) possibilities to enforce these provisions. We also know from other narratives that women could have legal capacity in specific sets of circumstances and when it came to hold- 
ing land, which was the ultimate source of wealth and power in the Middle Ages (fiefs, in particular), they could be vested with (political) power, regardless of what may have been laid down in customary law. The context of customary law, such as the Coutumier discussed in this paper, is not strictly prescriptive in the way we consider legal provisions today. When pragmatics demanded it, rules could be adapted and this created windows of opportunities for women to enhance their de facto legal capacity. But, as Tanner argued, by the fifteenth century the practice of customary law had been coupled with new administrative structures and was transformed into a legal system that was less open to bending of rules in face of pragmatic considerations. 


\section{Bibliography}

\section{Primary sources}

Britton, Francis Nichols, ed. Oxford: Clarendon Press, 1865.

Coutumier d'Artois, Adolphe Tardif, ed. Paris: Alphonse Picard, 1883.

Coutumes de Beauvaisis, Philippe de Beaumanoir (Amédée Salmon, ed.), Tome I \& II. Paris: Alphonse Picard et Fils, 1899.

Coutumiers de Normandie, Ernest-Joseph Tardif, ed. 2 tomes, 3 volumes; tome I, $1^{\text {ère }}$ partie, Le Très Ancien Coutumier de Normandie, texte latin, Rouen: Cagniard, 1881; tome I, $2^{\mathrm{e}}$ partie, Le Très Ancien Coutumier de Normandie, texte français et normand, Rouen/Paris: Lestringant/Picard, 1903; tome II, La Summa de legibus Normannie in curia laicali, Rouen/Paris: Lestringant/ Picard, 1896.

De Eruditione Praedicatorum by the Dominical Humbert de Romans. 1277/1889, printed edition by J. Berthier can be found on: https://archive.org/details/ HumbertusOpera18892

Ranulf de Glanvill (12th c./1604) Tractatus de Legibus \& Consuetudinibus Regni Angliae, www.heinonline.org

Isidore of Seville The Etymologies of Isidore of Seville, S.A. Barney, W.J. Lewis, J.A.

Beach, O. Berghof, transl. 2006. Cambridge: CUP.

Livre de Manières by Etienne Fourgères (1168-1178). A printed edition edited by

F. Talbert can be found on https://archive.org/details/LeLivreDesManieres

La Très ancienne Coutume de Bretagne, Marcel Planiol, ed. Rennes: J. Plihon et L. Hervé, 1896.

Querimoniae Normannorum, Leopold Delisle, ed. Recueil des historiens des Gaules et

de la France, tome XXIV, Paris: Imprimerie nationale, 1904, 1-73.

Registre criminal de la Justice de St. Martin des Champs de Paris, Louis Tanon, ed.

Paris: Leon Willem, 1660-1674/1877.

Recueil de Jugements de l'Echiquier de Normandie au XIII ${ }^{e}$ siècle, Leopold Delisle, ed. Paris: Imprimerie impériale, 1864.

\section{Secondary sources}

Aird, William. Robert Curthose, Duke of Normandy [1050-1134], Woodbridge: The Boydell Press, 2008. 
Beattie, Cordelia and Mathew Stevens. "Introduction: Uncovering Married Women." In Married Women and the Law in Premodern Northwest Europe, edited by Cordelia Beattie and Mathew Stevens, Gender in the Middle Ages 8, 1-10. Woodbridge: Boydell, 2013.

Bennett, Judith. Patriarchy and the Challenge of Feminism. Manchester: Manchester University Press, 2006.

Besnier, Robert. "Les Filles dans le droit successoral normand." Legal History Review/Tijdschrift voor Rechtsgeschiedenis, vol.10, n² (1930): 488-506.

Butt, David, Rhondda Fahey, Susan Feez, Sue Spinks and Colin Yallop, eds.. Using Functional Grammar. An Explorer's Guide. Sydney: Macquarie University, 2000.

Davy, Gilduin. Le duc et la loi: héritages, images et expressions du pouvoir normatif dans le duché de Normandie, des origines à la mort du Conquérant: fin du IXe siècle - 1087. Paris: De Boccard, 2004.

Gilissen, John. "La femme dans l'ancien droit belge." Recueils Société Jean Bodin, vol. XII, 1962.

Gilissen. John. "Le statut de la femme dans l'ancien droit belge" in La femme, Recueils de la Société Jean Bodin pour l'histoire comparative des institutions, 255-321. Bruxelles, 1958.

Hagger, Mark. "Secular Law and Customs in Ducal Normandy, c. 1000-1144." Speculum 85 (2010): 827-867.

Haskins, Charles. Norman Institutions. Cambridge: Harvard University Press, 1918. Hawkes, Emma. "The 'Reasonable' Laws of Domestic Violence in Late Medieval England." In Domestic Violence in Medieval Texts, edited by Eve Salisbury, Georgiana Donavin and Merrall Llewelyn Price, 57-70. Gainesville: University Press of Florida, 2002.

Heirbaut, Dirk. "Who Were the Makers of Customary Law in Medieval Europe - Some Answers Based on Sources about the Spokesmen of Flemish Feudal Courts." Legal History Review, 75/3 (2007): 257-274.

Howell, Martha. The marriage exchange : property, social place, and gender in cities of the Low Countries, 1300-1550. Chicago: The University of Chicago Press, 1998.

Hutton, Shennan. Women and economic activities in Ghent. New York: Palgrave Macmillian, 2011.

Kittell, Ellen. "Guardianship over Women in Medieval Flanders: a reappraisal." Journal of Social History, vol. 31, no. 4 (1998): 897-930. 
Kittell, Ellen. "Testaments of two cities: A comparative analysis of the wills of medieval Genoa and Douai." European Review of History, 5/1 (1998): 47-82. Laske, Caroline. Law, Language and Change. Leiden: Brill Nijhoff, 2020.

Lewis, Katherine. "Women, Testamentary Discourse and Life-Writing in Later Medieval England." In Medieval Women and the Law, edited by Noël Menuge, 57-75. Woodbridge: The Boydell Press, 2000.

MacCormick, Neil and Ota Weinberger. An Institutional Theory of Law. Dordrecht: Kluwer, 1986.

Mostert, Marco, and Paul Barnwell, eds. Medieval Legal Process. Physical, Spoken and Written Performances in the Middle Ages. Turnhout: Brepols, 2011.

Naessens, Mariann. “Judicial Authorities' Views of Women's Roles in Late Medieval Flanders." In The Texture of Society: Medieval Women in the Southern Low Countries, edited by Ellen Kittell and Mary Suydam, 51-77. New York: Palgrave Macmillan, 2001.

Neveux, François. "Le contexte historique de la rédaction des coutumiers normands." Annales de Normandie, 2011/2: 11-22.

Pollock, Frederick and Frederic Maitland. The History of English Law before the Time of Edward I, Vol. I \& 2, Cambridge: CUP, 1898/1968.

Sand, George. Indiana, Paris: Éditions Gallimard, 1832/1984.

Searle, Eleanor. "Women and the Legitimisation of Succession." In, Proceedings of the Battle Conference on Anglo-Norman Studies, vol. 3 (1980): 159-170.

Searle, John. The Social Construction of Reality. London: Allen Lane, 1995.

Shahar, Shulamith. The Fourth Estate. A history of women in the Middle Ages. London: Methuen, 1983.

Stafford, Pauline. "Women in Domesday." Reading Medieval Studies, vol. 15 (1989): 75-94.

Stafford, Pauline. "Women and the Norman Conquest." Transactions of the Royal Historical Society, vol. 4 (1994): 221-249.

Tanner, Heather. "Women's Legal Capacity: Was The Thirteenth Century a Turning Point?" In: Paradigm Shifts During the Global Middle Ages and the Renaissance, edited by Albrecht Classen, 81-98. Turnhout: Brepols, 2019.

Thompson, Victoria. "Women, Power and Protection in Tenth- and EleventhCentury England." In Medieval Women and the Law, edited by Noël Menuge, 1-17. Woodbridge: The Boydell Press, 2000. 
For further titles see: www.ebverlag.de

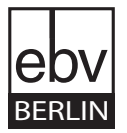

EBVERLAG DR. BRANDT

\section{WWW·EBVERLAG·DE}

Rainer Kuhl Tel.: 00493068977233

Jägerstraße 47 Fax:0049 3091607774

13595 Berlin E-Mail: post@ebverlag.de 
This paper examines the legal capacity which secular women enjoyed or lacked in late medieval Normandy. The issue is particularly relevant to decoding asymmetrical dependencies, since a lack of legal capacity was the quintessential expression of women's inferior position and dependency in society and in the eyes of the law. The research discussed in this paper reveals the extent of that legal dependency in real, rhetorical and linguistic terms. It involves examining the textual and semantic representation of women in Norman customary law texts, by using diachronic linguistics and terminological methodologies. The study confirms the assumption that women in thirteenth century Normandy had relatively low legal capacity and found themselves in asymmetrical dependencies on men, especially on their husbands. The narrative told in the Coutumier of men is not only more substantial but also considerably more varied and thus contextually richer. The approach has allowed us to go beyond content analysis and get a better understanding of the actual social experience of women's legal capacity by compounding information and data from analysis of content, meanings, terminology and discourse and, hence, providing a contextualized understanding of the dependencies in which women existed in their daily lives.

\section{THE AUTHOR}

Caroline Laske holds graduate and post-graduate degrees in law from the University of Cambridge, in linguistics and translation studies from the University of Birmingham and $\mathrm{ahD}$ in legal history from the University of Ghent. She is a Heinz Heinen Fellow at the Bonn Center of Dependency and Slavery Studies, a research fellow at the Ghent Legal History Institute and a lecturer at the UCLouvain. Her interdisciplinary research lies at the intersection of law, history and language, applying linguistic analysis to study legal history \& concepts, comparative law and translation. 